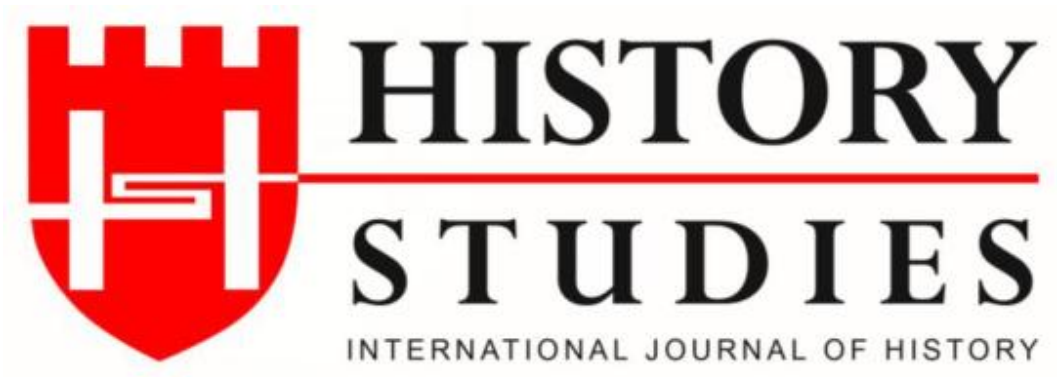

ISSN: 13094173 (Online) 1309 - 4688 (Print)

Volume 10 Issue 9, p. 21-43, December 2018

DOI Number: 10.9737/hist.2018.673

\title{
19. Yüzyılda İnşa Edilen Fabrika Yapılarının Kent Üzerindeki Olumsuz Etkileri ve Osmanlı Yönetiminin Çözüm Arayışları ${ }^{1}$ \\ The Negative Effects of 19th Century Factory Buildings on the City and Ottoman Administrative Solutions
}

Dr. Didem BOYACIOĞLU

(ORCID: 0000-0003-3320-3405)

Istinye Üniversitesi - Ístanbul

Öz: Osmanlı fabrika yapıları devletin modernleşme projesinin bir parçası olarak ağırlıklı olarak 19. yüzyılda inşa edilmiş yapılardır. Batı'dan ithal edilmiş bir yapı tipi olan fabrikaların geleneksel Osmanlı kentlerinin fiziksel gelişimine etkisi ve kentte yarattı̆g sorunlar ile Osmanl yönetiminin konuyla ilgili çözüm arayışları bu makalenin konusunu oluşturmaktadır. Osmanlı yönetimi bu sorunları nizamnameler hazırlamak, fabrikaların yer seçimi ile ilgili kısıtlamalar getirmek ve ruhsat alımlarını düzenlemek suretiyle çözmeye çalışmış, kamu sağllğını gözeten kararlar almıştır.

Anahtar Kelimeler: 19. yüzyll, Osmanlı sanayileşmesi, kent, fabrika

Abstract: Ottoman factory buildings were mostly built in 19th century as a part of the state's modernization project. As a building type originated from the West, the effects of the factories on the physical development of the traditional Ottoman cities, the problems they caused in the city and the efforts of the Ottoman administration for the solution of these problems are aimed to be discussed within the scope of this paper. Ottoman administrative solutions seem to be concentrated on the public health and depend on some regulations and restrictions about the construction of the factories.

Keywords: 19th century, Ottoman industrialization, city, factory

\section{Giriş}

Sanayi Devrimi ile birlikte İngiltere'de başlayıp, oradan Avrupa'nın diğer devletlerine yayılan ekonomik ve sosyal dönüşüm kent yapısında büyük değişikliklere neden olmuştur. Osmanlı kentleri için Manchester, Liverpool, Londra ölçeğinde birer sanayi kentine dönüşecek ekonomik, demografik, teknolojik ve siyasi koşullar yeterince olgunlaşmamış olmakla birlikte büyük çoğunluğu 19. yüzyılda inşa edilmiş olan fabrika yapılarının kentlerin fiziksel gelişiminde önemli etkileri olmuştur.

Makale kapsamında 19. yüzyılda Osmanlı kentlerinde yaşanan sosyal ve fiziksel değişimin bir parçası olarak inşa edilen fabrika yapılarının kentle ilişkisi, kent üzerinde yarattığı olumlu veya olumsuz etkileşimler ve Osmanlı yönetiminin bu konudaki tavır ve tutumları özgün belgeler ışığında ele alınmıştır.

\footnotetext{
${ }^{1} \mathrm{Bu}$ makale yazarın İTÜ Mimarlık Tarihi Doktora Programında Prof. Dr. N. Turgut Saner danışmanlığında hazırlamış olduğu doktora tezinden türetilmiş olup, TÜBİTAK- BİDEB ve İTÜ- BAP fonları kapsamında desteklenmiştir.
} 


\section{Sanayi Devrimi ve Kent}

Sanayi Devrimi öncesinin feodal kentlerini biçimlendiren etkenler toplumun ortak değer yargıları, gelenekleri ile merkezi otorite ve aristokrasinin kararlarıdır. Sanayi Devrimi öncesi kentleri yoğun olarak sur içinde yapılaşmış, mekanda fonksiyonel ayrışmanın fazla olmadığı, işyerlerinin konutla birlikte veya konuta yürüme mesafesinde konumlandığ Üretim odağı olmaktan çok dışarıdan alınan malların veya hammaddelerin değiş-tokuş edildiği pazar yerleridir. Dolayısıyla tarıma ve ticarete dayalı bir ekonomi söz konusudur. İmalat büyük ölçüde yerel topluluk sınırları içerisinde faaliyet gösteren çeşitli meslek örgütleri olan loncaların egemenliği altındadır. ${ }^{2}$

19. yüzyıla kadar sanayi dağınık, desantralize bir yapıya sahiptir. Güçlü akarsular üzerine kurulan sanayi yapıları doğa içerisinde pitoresk bir görünüm oluşturmaktadırlar. 18. yüzyıl sonlarında yaşanan teknolojik gelişmeler ile makineleşme, üretim organizasyonu ve ölçeğinin değişmesine neden olmuş ve fabrika sistemine geçilmiştir. Buhar teknolojilerinin yaygınlaşması, odun kömürü yerine taş kömürünün kullanılmaya başlanması, demiryollarının inşası ve yelkenli gemilerin yerini yavaş yavaş buharlı gemilerin alması ile doğa içerisindeki sanayi yapılarının yerini madenler çevresinde veya madenlerin su veya demiryolu ile ulaşılabilir olduğu noktalarda kurulan yeni sanayi yerleşkeleri almaya başlamıştır. Doğal güç kaynaklarından buhara geçiş ile yere bağımlılık ortadan kalktığından işgücünün yoğun olduğu kentlere yönelen sanayi üreticileri emek ve sanayinin belli merkezlerde toplanmasına neden olmuşlardır. ${ }^{3}$ Sanayinin kent merkezlerini tercihinde banka ve finans merkezlerinin kentlerde toplanması, ucuz işçi temini, kentlerin kavşak noktalarında bulunmasının ithalat ve ihracata getirdiği kolaylıklar rol oynamıştır.

Sanayinin yarattığı bu istihdam hacmi kentleri çekici hale getirmiştir. Bu dönemde kırsal kesimden kente yapılan göçlerle kentlerdeki nüfus yoğunluğu inanılmaz bir şekilde artmıştır. Örneğin 1760'larda nüfusu on iki bin olan Manchester kenti 19. yüzyılın ortasında dört yüz bin nüfusa ulaşmış, Londra'nın nüfusu ise iki buçuk milyonu bulmuştur. ${ }^{4} \mathrm{Bu}$ dönemde yaşanan nüfus hareketliliklerinde çiftçinin topraksızlaştırılması sürecinin de etkisi büyüktür. İşsiz kalan tarım işçisi yeni istihdam alanlarının oluştuğu kentlere akın etmiştir. Hızlı nüfus artışı ile beraber kentler sur dışına taşarak genişlemiş ve sur dişında yeni yerleşim yerleri, işçi mahalleleri oluşmuş̧tur. 19. yüzyılda tramvay, metro gibi toplu taşıma araçlarının da kullanılmaya başlanması ile yürüme mesafelerine göre şekillenen Ortaçağ yaya kentleri bambaşka bir boyut kazanmıştır. Yeni yerleşim yerleri genelde merkezden dışa doğru genişleyen bir yapıdadır. Buna göre merkezde bir ticaret bölgesi ve fabrika, onu kuşatan işçi konutları, en dış halkada ise ilk banliyö yerleşimleri sayılabilecek yeni orta sınıfın evleri yer almaktadır. ${ }^{5}$

Sanayi Devrimi ile birlikte ticari sermaye sanayi sermayesine dönüşmüş ve bu sermayeyi elinde tutan burjuvazi sınıfı kendi ekonomik gücüne paralel bir siyasi güç talep etmeye başlamıştır. Merkezi otorite zayıflamıştır. Adam Smith'in liberal doktrini "laissez faire" (bırakınız yapsınlar) kamu müdahalelerinin olmadığı serbest piyasa ortamını savunur. Tüm girişimler özel girişim tarafindan yapılmalı, buna ne yerel yönetimlerin ne de merkezi hükümetin hiçbir ölçekte müdahalesi olmamalıdır. Fabrikaların yer seçimi ve işçi konutlarının

2 Sevilay Kaygalak, "Osmanlı'da Kentsellik ve Kentler: Kent Tarihi Yazımında Kültürelciliklerin Ötesine Geçebilmek", Mülkiye Dergisi, C. XXIX, S. 246, 2005, s.19-36.

3 James F. Munce, Industrial Architecture, An Analysis of International Building Practice, F.W. Dodge Corporation, New York 1960, s. 3.

${ }^{4}$ Leonardo Benevolo, Avrupa Tarihinde Kentler, Literatür Yayınları, İstanbul 2006, s. 165.

${ }^{5}$ David C. Goodman- Colin Chant, The European Cities and Technology. Routledge, London 1999, s. 9. 
yapımının yanısıra, kente su sağlanması, çöpün toplanması gibi her türlü hizmet özel girişim tarafından sağlanmalıdır. Ancak merkezi otoritenin bilinçli olarak dışında bırakıldığı bu süreç kentlerin büyük bir hızla büyüdüğü ve değiştiği bir dönemde büyük bir düzensizlik ve kaos ortamına neden olmuştur. ${ }^{6}$

Özel girişimin ön plana çıkması ile birlikte üretimin niteliksel ve niceliksel olarak denetimini sağlayan loncalar devre dışı kalmış, herşey serbest piyasa koşullarına bırakılmıştır. Loncaların sağladığı üyeler arası sosyal dayanışma ortadan kalkınca, işçi sınıfının yaşam ve çalışma koşulları da serbest piyasanın merhametine kalmıştır. Sosyal açıdan bakıldığında fabrika, işçilerin evlerinde veya küçük imalathanelerde bağımsız olarak iş yapma gücünü elinden almıştır. ${ }^{7}$ Artık kapitalist düzenin belirlediği çalışma ve yaşam koşullarına uyma zorunluluğu vardır. İşçiler havalandırmasız, yetersiz aydınlatmaya sahip basık tavanlı mekanlarda çalışmakta, fabrikaların arasına sıkışmış dipdibe konutlarda kirli havayı soluyarak yaşamaktadır. Plansız, altyapısız yerleşimler nedeniyle verem, kolera gibi salgın hastalıklar başgöstermektedir.

1792-1815 yılları arasındaki Napolyon Savaşları'ndan önce Boulton, Wedgewood, David Hale gibi bazı sanayicilerin çalışanların yaşama ve çalışma koşullarına büyük özen gösterdiği istisnai durumlara rastlanmaktadır. Bu sanayiciler fabrikalarla birlikte okullar, dispanserler kurmuşlar, ilk defa hastalık yardım planları geliştirmişlerdir. Ancak bu çabalar yeterince örnek teşkil etmemiştir. Savaş sırasında çoğu el değiştiren fabrikaların yeni sahipleri İngiltere'de Sanayi Devrimi'nin en acımasız koşullarının yaşanmasına neden olmuşlardır. Sonuç olarak kentleri biçimlendiren yeni güçler ortaya çıkmıştır. Fakat toplum bunları denetleyecek tecrübe ve yasal çerçeveden yoksundur.

Sanayi kentinin karşı karşıya kaldığı en büyük iki sorundan biri sayıları hızla artan fabrika yapılarının oluşturduğu kirlilik ve buna bağlı olarak gelişen hastalık ve salgınlar, diğeri ise yangınlardır. (Ek 1) Bu problemlerin çözümüne yönelik uğraşlar ise mimaride ve kentsel tasarımda 20. yüzyıla damgasını vuracak gelişmelerin yolunu açmıştır.

Charles Dickens'ın 1854 yılında kaleme aldığ romanı dönemin sanayi kentlerinin içinde bulunduğu durumu çok iyi özetler. Dickens romanında "Coketown" adını verdiği sanal bir kent yaratmıştır. Bu kent:

Kırmızı tuğlaların kentiydi, ya da dumanla küller izin verseydi, kırmızı tuğladan bir kent olacaktı. Şimdiyse bir yerlinin boyalı suratı gibi kırmızı siyahtı. Fabrikaların ve yüksek bacaların kentiydi. Bacalardan sayısız yılan lar gibi dumanlar yükseliyor, birbirine dolanıyor, hiç çözülmüyordu... Kapkara bir kanalı, kötü kokulu mor boyalı suların aktığı bir nehri, pencerelerinden bir yığın gürültünün yayıldığı fabrika binaları, deli bir filin başını sallaması gibi inip kalkan, inip kalkan buhar pistonları vardı. Birbirine benzeyen bir iki büyük caddeyle, birbirine benzeyen bir yığın küçük sokakta, birbirine benzeyen bir yığın insan aynı saatte gider gelir, sokaklarda aynı sesleri çıkarır, aynı işi yapardı...

Dickens'in betimlemesinin zamanın Londra, Manchester gibi büyük sanayi kentlerine gönderme yaptığı açıktır. İngiltere Sanayi Devrimi'nin merkezinde olmasına rağmen kamu sağlı̆̆ 1 ile ilgili etkin yasal çözümlere çok geç kavuşmuştur. Bunda kapitalizmin serbest girişimi destekleyen ve her türlü kamu müdahalesini reddeden yaklaşımının etkisi büyüktür. Dolayısıyla hazırlanan ilk kanun ve nizamların içeriği de son derece kısıtlıdır. Örneğin, 1802

${ }^{6}$ Benevolo, a.g.e., s. 170-172.

${ }^{7}$ Munce, a.g.e., s. 3.

${ }^{8}$ Charles Dickens, Zor Zamanlar, çev. Füsun Elioğlu, Oda Yayınları, İstanbul 2017, s. 24. 
yılında fabrikaların koşullarının iyileştirilmesi için İngiltere parlemantosuna sunulan kanun tasarısı, fabrikaların bütün duvar ve tavanlarının yılda iki kez beyaza boyanması ve yeterli havalandırmanın sağlanabilmesi için pencere boyutlarının büyütülmesi dışında herhangi bir zorunluluk getirmemektedir. ${ }^{9} 1830$ yılından sonra yayılan kolera salgınının ardından koruyucu tedbirler almak ve hastaları tecrit işiyle meşgul olmak üzere sağlık meclisleri (Boards of Health) kurulmuş, ancak salgının sona ermesiyle ortadan kaldırılan bu meclisler fazla uzun ömürlü olamamıştır. Bununla beraber bu tarihten sonra devletin hem eski hem de yeni kent merkezlerindeki sağlık koşullarının iyileştirilmesi hususuna müdahil olmaya başladığı görülmektedir. Kentin altyapı eksikliğinden kaynaklanan sağlık sorunları önceliklidir. Bu nedenle 1848 yılındaki kolera ve suçiçeği salgınının ardından Sağlık Bakanlığı kurulmuş, aynı yıl çıkarılan Kamu Sağlığı Kanunu (Public Health Act) ile yerel yönetimlere sağlık hususunda yetkiler tanınmış ve Sağlık Meclisleri (Boards of Health) yeniden kurulmuştur. ${ }^{10} \mathrm{Su}$ kaynaklarının iyileştirilmesi ve kanalizasyon sisteminin geliştirilmesi gibi işler Sağlık Meclisleri'nin insiyatifindedir. Fabrikalardan çıkan dumanın zararlarının önlenmesi ile ilgili yasalar ise 1840'll yıllardan itibaren yürürlüğe girmiştir. Bu yasalar kapsamında fabrika sahiplerinden istenen işletmelerinde daha gelişmiş kazanlar kullanmalarıdır ancak bu yaptırımın dumanı engellemeye bir faydası yoktur. Yasanın uygulanması güçtür ve denetimler de pek yapılamamaktadır. ${ }^{11}$

Sanayi kentinin beraberinde getirdiği yeni ihtiyaçlar ve başta sağlık olmak üzere yol açtığı çeşitli sorunlar felsefi ve siyasi açıdan pek çok eleştiri ve önerilere neden olmuştur. Yeni sanayi toplumunun sorunlarına çözüm aramak üzere geliştirilen ütopik ve eleştirel yaklaşımlar Avrupa'da modern anlamda kent planlamasının temelini oluşturur. 19. yüzyıl ütopyacıları ve siyasetçileri Rönesans düşünürlerinin ideal kent ütopyalarından farklı olarak, ideal toplum arayışı içinde toplumsal sorunlara çözüm aramışlardır. Dönemin ütopyacılarından Owen'ın 1817'de, Fourier'in 1822 'de yaptı̆ğ ve bir bölümü $1820-1850$ yılları arasında gerçekleşen alternatif yaşam önerileri ile Marx ve Engels'in hem kendiliğinden oluşan, hem de planlı sanayi yerleşmeleri konusunda yaptıkları eleştiriler önemlidir. ${ }^{12} 19$. yüzyılın sonlarında İngiltere'de başlayıp diğer Avrupa ülkelerine yayılan Ebenezer Howard'ın "bahçe-kent" akımı, 20. yüzyıl başlarında ise Tony Garnier'in “endüstri kenti” yaklaşımı kent planlamacılı̆̆ 1 açısından önemli birer dönüm noktası oluşturmuştur. ${ }^{13}$

\section{Sanayi Devrimi Sonrası Osmanlı Kentleri}

Sanayileşme Batı'da büyük bir toplumsal dönüşümle birlikte modernleşme ve kentleşme olgularının ateşleyicisi iken, Osmanlı' da devletin “modernleşme projesi”nin bir bileşenidir.

Sanayi Devrimi sonrası Osmanlı kentlerinin gelişimi büyük oranda devleti ve toplumu çağdaşlaştırmak için öngörülen değişme ve düzenlemeler bağlamında gerçekleşmiştir. Bu düzenlemeler büyük ölçüde hukuk ve yönetim alanında olsa da aynı zamanda Osmanlı yönetici elitinin arzuladığı Batılı kent imgesinin yaratılmasına da hizmet etmiştir. ${ }^{14}$ Resmi yapılar, kışlalar, okullar, ticaret ve eğlence yapıları, fabrikalar gibi Batı'dan ithal edilen plan tipleri ve üsluplara göre inşa edilen büyük ölçekli yapılar gerek görünümleri ve gerekse sosyal ve

\footnotetext{
${ }^{9}$ Munce, a.g.e., s.4.

${ }^{10}$ Erol Bilik, “İngiltere'de Sağlık Hizmetleri”, Ankara Üniversitesi Hukuk Fakültesi Dergisi, C.7, S. 1-4, 1950, s. 194-195.

${ }^{11}$ Goodman, a.g.e., 1999, s. 9.

${ }^{12}$ Benevolo, a.g.e., s. 172.

${ }^{13}$ Gaye Birol, "Modern Mimarlığın Ortaya Çıkışı ve Gelişimi”, Megaron Mimarlar Odası Balıkesir Şubesi Dergisi, S.1, 2006, s. 3-16.

${ }^{14}$ Murat Gül- Richard Lamb, "Mapping, Regularizing and Modernizing Ottoman İstanbul: Aspects of the Genesis of the 1839 Development Policy”. Urban History, C.31, S.3, Cambridge 2004, s.420-436.
} 
kültürel hayatta yarattıkları değişimlerle Osmanlı kentlerinin silüetini önemli ölçüde değiştirmişlerdir. ${ }^{15}$

16. yüzyllın içe dönük Osmanlı kenti 19. yüzyılda değiş̧en ticari ilişkiler nedeniyle dışa dönük bir hale gelmiştir. Avrupa'nın hammadde ve tarım ürünleri ihtiyacının karşılandığı ve bitmiş ürünün pazarlandığı bir mecra haline gelen Osmanlı topraklarında deniz yoluyla sağlanan dış ticaret liman kentlerinin büyümesine ve özellikle deniz kıyısında yeni yerleşimlerin oluşmasına neden olmuştur. Doğu ile Batı arasında yeniden tanımlanan ticaret iliş̧kileri yeni bir ulaşım ağı ihtiyacını doğurmuştur. Bu ağın dışında kalan bölgelerde ulaşım geleneksel şekilde kervanlarla sürdürülürken, ağın üzerindeki kentler arasındaki ulaşım çoğunlukla yabancı sermaye yatırımları ile oluşturulan demiryolu şebekeleri ile gerçekleşmektedir. ${ }^{16}$ Batılı devletlerin hammadde akışını hızlandırmak, ucuz taşımacılık imkanları yaratmak ve bölge üzerinde ticari ve siyasi üstünlük kurmak üzere inşa ettikleri demiryolları fiziksel çevreyi büyük oranda etkilemiş ve yeni gelişim aksları oluşturmuştur. ${ }^{17}$

Demiryolu ile birlikte sanayi yapıları için hammadde ve ticari ürünün nakliyatında deniz ulaşımının yanısıra kara ulaşımı da mümkün olabilmiştir. Bu da buralardaki sanayi ve ticaret yükünü arttırmış, önemli kentsel değişikliklere yol açmıştır. Örneğin İzmit kent tarihinde Haydarpaşa-İzmit hattının önemi büyüktür. Osmanlı Devleti 1890 yılında İzmit Körfezi'nin bitimindeki bataklıkların kurutulup sanayileşmesi için İngiliz Kraliyet firmasına fermanla izin vermiştir. İmtiyaz sahibi Dr. J. L. Sabuncu tarafından Bab-1 Ali'ye arz edilen rapor öncelikle İzmit'in ticari ve askeri öneminden bahsetmekte, İstanbul'dan Ankara'ya uzanan demiryolunun İzmit'ten geçmesi ve bu demiryolunun aynı zamanda Basra' ya uzanan kolları sayesinde bölgenin ikinci İstanbul olma yolunda ilerlediğini anlatmaktadır. Toplam 39000 dönümlük bir arazinin ıslahı söz konusudur. İmtiyaz sahibi toprağı işleme, satma, üzerinde bürolar, evler, fabrikalar, rıhtım, iskele ve antrepolar kurma hakkına sahip olacaktır. Sabuncu, buraya kurulacak fabrikalarla birlikte İzmit'in bütün Doğu'nun Manchester ve Birmingham' olacağını ifade etmektedir. ${ }^{18}$ Osmanlı Devleti'nin o yıllarda İzmit'i bir sanayi kenti olarak tahayyül ettiği açıktır.

1874 y1lında hizmete giren ve İstanbul'u Avrupa'ya bağlayan demiryolu hattı Marmara sahili boyunca ilerleyerek Topkapı Sarayı'nın bahçesinden geçip Sirkeci'de son bulur. Demiryolunun tarihi yarımadaya ve Haliç'e gelmesi kentsel dokuda önemli değişikliklere yol açmış, 18. yüzyılda çok sayıda yalının yer aldığı Haliç kıyılarında sanayi ve ticaret tesislerinin sayıca artmasına ve yalıların yerini yavaş yavaş bu tesislerin almasına neden olmuştur. Ayrıca Küçükçekmece, Bakırköy ve Yeşilköy gibi banliyöleri şehir merkezine bağlayan bu hat sayesinde Marmara kıyısı boyunca yer alan fabrikaların hammadde ve bitmiş ürün nakliyesinde büyük kolaylıklar elde edilmiştir. ${ }^{19}$

19. yüzyılda Osmanlı yönetiminin İstanbul, İzmir gibi büyük şehirler için ulaşım ağının modernleştirilmesi ve kent imajının geliştirilmesi amacıyla hazırlatmış olduğu iddialı proje ve

\footnotetext{
15 İlhan Tekeli, “19. Yüzyılda İstanbul Metropol Alanının Dönüşümü”, Ed. Paul Dumont, François Georgeon, Modernleşme Sürecinde Osmanlı Kentleri, Tarih Vakfı Yurt Yayınları, İstanbul 1992, s. 19-30.

16 19. yüzyılda Osmanlı Devleti'nde yabancı sermayenin en karlı yatırım alanlarından biri altyapı hizmetleridir. Tramvay, rıhtım inşaatı, havagazı, elektrik ve su gibi altyapı hizmetleri büyük ölçüde yabancı şirketler tarafından kurulmuş ve işletilmiştir. Gevher Acar, Tanzimat Dönemi Fikir ve Düşünce Hayatının Mimari Alana Yansıması, (Mimar Sinan Üniversitesi Sosyal Bilimler Enstitüsü Yayınlanmamış Doktora Tezi), İstanbul 2000, s. 65-69.

${ }^{17}$ Hümeyra Birol Akkurt, 19. Yüzyll Batılılaşma Kesitinde Bornova, Buca Levanten Köşkleri Mekansal Kimliğinin İrdelenmesi, (Dokuz Eylül Üniversitesi Fen Bilimleri Enstitüsü Yayınlanmamış Doktora Tezi), İzmir 2004, s. 35.

${ }^{18}$ Avni Öztüre, Nicomedia İzmit Tarihi.,Çeltüt Matbaacılık, İstanbul 1969, s. 144-149.

${ }^{19}$ Zeynep Çelik, 19. Yüzyılda Osmanlı Başkenti, Değişen İstanbul, Tarih Vakfı Yurt Yayınları, İstanbul 1998, s. 82.
} 
planlar bulunmaktadır. ${ }^{20}$ İstanbul için hazırlanan projelerin hiçbirisinde sanayiye dair bir planlamadan bahsedilmez. Bununla birlikte, 1851-1856 yılları arasında İzmir'e davet edilen İtalyan mühendis Luigi Storari'nin hazırladığı proje dahilinde sanayiye ilişkin öneriler de bulunmaktadır. Storari kentin ilk kadastral ve 1/5000 ölçekli planını hazırlamış, kent bütünündeki arazi kullanımına ve yangın alanlarına yönelik fikirler üretmiştir. Kurulması düşünülen sanayi alanı için ise Punta (bugünkü Alsancak) bölgesini önermiş, bu bölgeye ilişkin gridal bir plan hazırlamış ve plana İzmir-Aydın demiryolu hattının tesis merkezi olarak seçilen alanı da eklemiştir. ${ }^{21}$ Nitekim, Punta Tren İstasyonu'nun 1861 yılında tamamlanmasının ardından istasyon çevresinde imalathane ve depoların sayısı fazlalaşmıştır. Demiryollarının işletmeye açılmasıyla İzmir ile Gediz ve Menderes vadileri arasındaki ürün akışı hızlanınca, İzmir Limanı'na büyük tonajlı gemilerin rahatça yanaşabileceği bir rıhtımın yapılması gündeme gelmiştir. 1867'de bir İngiliz şirketi tarafından başlayan liman inşaatı 1873 yılında tamamlanmıştı. ${ }^{22}$ İstasyon ile liman arasındaki ticari mal akışını sağlayabilmek amaciyla Kordon boyunca belli zamanlarda ve geceleri çalışan bir tren hattı döşenmiştir. İnşas biten Pasaport Limanı ile birlikte semt, liman ve istasyon çevresinde gelişen yeni bir merkez haline gelmiştir. ${ }^{23}$ Liman çevresi ve kıyı bandı gümrük binası ve büyük han yapılarının yanısıra tüccarların konaklaması için inşa edilen oteller, konsolosluklar, köşkler ve eğlence yerleri ile dolmuştur. Rıhtım boyu ve rıhtıma paralel sokaklarda Levanten ve varlıklı azınlıklara ait prestij konutları yer alırken, istasyon civarı imalathane, depolar ve işçi sınıfına ait konut birimlerinin yer aldığ 1 bir bölge haline gelmiştir. ${ }^{24}$

Kent merkezleri emek pazarına, tüketiciye ve altyapı tesislerine kolay ulaşılabilmesi açısından sanayi faaliyetleri için en çok talep edilen yerlerdir. Bununla birlikte sanayi yapılarının kent içerisinde inşası her dönemde çeşitli problemlere yol açmıştır.

\section{Fabrikaların Kentte Yarattığı Sorunlar ve Osmanlı Yönetiminin Çözüm Arayışları}

Sanayi yapılarının kentte yarattığı problemlerin başında yangınlar, patlamalar, kirlilik ve koku problemleri gelir. Örneğin derinin işlendiği yer olan debbağhaneler kötü kokular yayarlar. Meskenlerden uzakta ve hakim rüzgar yönleri dikkate alınarak kurulmaları gerekir. İmalat aşamasında yumuşaması için deri bir süre su içinde bekletilir. ${ }^{25} \mathrm{Bu}$ nedenle debbağhanelerin su kenarında kurulması zorunludur. Ancak şehir suyunu bozmamaları için akarsuların şehre giriş kısmında debbağhane kurulması yasaklanmıştır. Şehir içinde kurulan veya şehrin gelişmesiyle şehir içinde kalan debbağhanelerin kaldırılarak şehir dışına taşınması gereklidir. ${ }^{26} 1838$ yllına tarihlenen bir belgede salhane ( kesimevi), debbağhane ve yağhane gibi kötü koku veren ve havayı bozan işletmelerin şehir dışına taşınması gerektiği anlatılmaktadır. Yine 1838 yılında oluşturulan Karantina nizamnamesinde de debbağlar, boyacılar ve deriyi pürüzsüz hale getirme işlemini yapan deri perdahtçılarının şehir dişına nakledilmesi hususu ele alınmıştır. ${ }^{27}$ Ancak bu imalathanelerin şehir dışına taşınması masraflı

\footnotetext{
${ }^{20}$ Çelik, a.g.e., s. 84-100.

${ }^{21}$ Akkurt, a.g.t., s. 35.

${ }^{22}$ Abdullah Martal, “16. Yüzyıldan 20. Yüzyıla Ticaret ve Sanayinin Gelişimi”, Ed. Enis Batur, Ǘ̧ İzmir, Yapı Kredi Yayınları, İstanbul 1992, s. 265.

${ }^{23}$ Eylem Şimşek, Endüstri Yapılarının Kültürel Miras Olarak Irdelenmesi ve Değerlendirilmesi: İzmir Liman Arkası Bölgesi Örneği, (Dokuz Eylül Üniversitesi Fen Bilimleri Enstitüsü Yayınlanmamış Yüksek Lisans Tezi), İzmir 2006, s. 87.

${ }_{25}^{24}$ Akkurt, a.g.t., s.56.

25 Zeki Tekin, Tanzimat Dönemine Kadar Osmanl İstanbul'unda Dericilik, (Marmara Üniversitesi Türkiyat Araştırmaları Enstitüsü Yayınlanmamış Doktora Tezi), İstanbul 1992, s. 61.

${ }^{26}$ Bu belge Karahisar-1 Sahib'de debbağhanelerin şehir dışına çıkarılması ile ilgilidir. BOA (Başbakanlık Osmanlı Arşivi),Cevdet/ Sihhiye (C.SH.), 28/1371, M. 19 Haziran 1845 (H. 13.C.1261).

${ }^{27}$ Tekin, a.g.t., s.14.
} 
bir iştir ve 1892 ve 1893 yıllarına ait belgelerden konunun belediyenin aldığı geçici önlemlerle çözülmeye çalışıldığı, ancak kapatılan yerlerin tekrar kaçak olarak açıldığı ve sorunun çözülememiş olduğu anlaşılmaktadır. Bu nedenle İstanbul'un çeşitli mevkilerinde, mahalle ve meskenler arasında bulunan paçavra ve kemik mağazalarıyla, derici, nişastacı, kirişçi ve tutkal kârhanelerinin yerleşim yerlerinden uzak mahallere taşınması konusu yeniden gündeme gelmiş ve bu esnafa şehir dışında uygun bir yerin bulunması işi kimyager Miralay Bunkoski Bey'e verilmiştir. Bunkoski Bey, hazırladığı raporda, Küçükçekmece Gölü dışında Hazine-i Celile-i Maliye katiplerinden İzzet Efendi'nin tasarrufu altındaki hanın kullanılmasını ve bir kısım esnafın hemen oraya gönderilmesini istemiştir. Fakat adı geçen yer pek ıssız olmadığından bu da geçici bir tedbir olarak görülmüş ve sonuç olarak, Küçükçekmece Gölü’nün son uç noktasında Kiremithane olarak anılan mekan hem esnafın deniz nakliyesine ve her vakit işleri başına gidip gelmesine müsait ve hem de tenha olduğundan uygun bulunmuştur. Fakat adı geçen mevkinin tayini durumunda burada çalışacak esnaf Makriköy ve Ayastefanos (Bakırköy ve Yeşilköy) gibi civar mahallere evlerini nakletmeye mecbur olacaklarından ve bu da masrafl bir iş olduğundan bu tür imalathanelerin şehir dışında imtiyazlı mağazalar şeklinde tesis ve inşası önerilmiş, fakat karara bağlanamamıştır. ${ }^{28}$

Özellikle imalatın ateşle gerçekleştiği sanayi yapılarında en çok korkulan şey yangın ve patlamalardır. 18. yüzyıl sonuna kadar Osmanlı Devleti de dahil olmak üzere hemen hemen bütün Avrupa ülkelerinde baruthaneler yerleşim birimleri içerisinde faaliyet göstermektedir. Ancak çıkan kazalarda meydana gelen hasarın boyutları da çok büyük olmaktadır. Şehremini Baruthanesi'nde 1698 tarihinde çarkların aşırı 1sınması ile ateş alan barut büyük bir patlamaya neden olmuş, patlamanın etkisi ile çevredeki yüzlerce ev yıkılmıştır. Bunun üzerine yeni baruthanenin şehir dışında bir yere taşınmasına karar verilmiştir. İlk olarak Kağıthane'deki eski baruthanenin tamiri düşünülmüştür. Böylece çarkların su gücüyle çalıştırılması da mümkün olacaktır. Sonbahar ve kışları 1ssız bir yer olmasına karşın ilkbahar ve yazları eğlence ve piknik alanı haline gelen Kağıthane civardaki köy ve çiftliklerin de mera olarak kullandığ bir yerdir. Burada yakılacak bir ateşin baruthaneye sıçraması durumunda meydana gelecek bir patlamanın çevreye ve insanlara büyük zarar vereceği açıktır. Bu nedenle eski baruthanenin tamirinden vazgeçilmiş, yeni baruthanenin, etrafinda hiç yerleşim birimi olmayan bir yerde, Kazlıçeşme ile Bakırköy arasında deniz kenarındaki bir alanda kurulmasına karar verilmiştir. ${ }^{29}$

Buhar enerjisinin Osmanlı topraklarına girmesiyle birlikte yavaş yavaş başka sorunlar da ortaya çıkmıştır. ${ }^{30} 1850$ 'li yıllara gelindiğinde gerek Haliç'ten geçen vapurların ve gerekse yüzyı başından itibaren sayıca çoğalan fabrikaların çıkardığı dumanlar İstanbul halkını rahatsız etmeye başlamıştır. 1872 tarihli bir belgede padişahın pis duman çıkardıkları için vapurların hareketini men ettiği belirtilmektedir. ${ }^{31}$ Elbette ki yaşanan hava ve çevre kirliliğini 19. yüzyıl Avrupası ile eş tutmak mümkün değildir. Bununla birlikte özellikle yüzyıl sonuna

\footnotetext{
${ }^{28}$ BOA, Dahiliye/ Mektubi Kalemi (DH.MKT), 2011/52, M. 18 Ekim 1892 (H. 26.RA.1310); BOA, Ylldız/Hususi Maruzat (Y.A.HUS), 268/109, M. 9 Ocak 1893 (H.20.C.1310).

${ }^{29}$ Zafer Gölen, Osmanlı Devleti'nde Baruthane-i Amire, Türk Tarih Kurumu Yayınları, Ankara 2006, s. 29-30.

${ }^{30} \mathrm{Bu}$ konudaki belgeler: Barutçubaşının Cibali kapısı ile Fener kapısı arasındaki sahilde kurmak istediği vapur fabrikasına ahalinin itirazları, BOA,Sadaret/ Nezaret ve Devair Evrakı (A.MKT.NZD.), 215/9, M. 28.02.1857 (H. 04.B.1273); İstinye'de sal üzerinde bulunan dakik fabrikalarından çıkan ve çevreyi huzursuz eden dumanlara karş1 tedbir alınmas1, BOA, A.MKT.NZD., 356/9, M. 17.06.1861 (H. 08.Z.1277); Logofet Bey ve ailesine dumanın zarar verdiğinden dolayı Şirket-i Hayriye vapurlarının bacalarının Yeniköy'de değil, İstinye'de durdurulmasına dair isteğinin yerine getirilmesi, BOA, Hariciye Nezareti/ Mektubi Kalemi (HR.MKT.), 263/77, M. 06.11.1858 (H.29.RA.1275); Üsküdar'da Paşalimanı'nda vaki değirmenin neşreylediği dumanın mazarratından bahisle muamele-i lazimenin icrası istirhamına dair ahalinin arzuhali, BOA, Şuray-ı Devlet (ŞD.), 3062/65, M. 07.10.1909 H.22.N.1327)

${ }^{31}$ BOA, Ylldız/Tahrirat-ı Ecnebiyye ve Mabeyn Mütercimliği (Y.PRK.TKM.), 1/6, M. 27.03.1872 (H. 17.M.1289).
} 
doğru fabrika dumanlarının yangın zannedilerek paniğe sebep olduğuna dair belgeler dumanın yoğunluğu ile ilgili fikir vericidir. ${ }^{32}$

Bir başka şikayet konusu ise sanayide ihtiyaç duyulan kömür depolarının yarattığ 1 kirlilik olmuştur. Nakliye kolaylığı açısından bu depolar genellikle demiryolu yakınında veya deniz kenarında yoğunlaşmıştır. Ancak yükleme ve boşaltma sırasında denize dökülen kömürlerden dolayı oluşan kirlilik şikayetlere konu olmuştur. ${ }^{33}$ Konuyla ilgili mazbatalarda örneğin Haliç’teki kömür depolarının Şehremaneti'nce istimlak edilerek şehir dışında başka bölgelere taşınması gündeme gelmiştir. ${ }^{34}$ Ancak bu gibi taleplerin herhangi bir sonuca ulaşmadığı anlaşılmaktadır.

Klasik dönem Osmanlı bürokrasisinin işleyişinde şikayet mekanizması önemli bir yer tutar. ${ }^{35}$ Osmanlı yönetiminin fabrikaların inşasına dair aldığ 1 kentsel ve mimari kararlarda da bu şikayet mekanizmasının etkili olduğunu varsaymak yanlış olmaz. 1840 yılının sonuna doğru Selanik’te yüzlerce ipek çıkrığının yanısıra otuz kadar iplik fabrikası bulunmaktadır. 1860'lı yılların başında bu sayının on dokuza düştüğü, buna karşıllk çevre köylerde on beş tane yeni fabrikanın kurulduğu görülmektedir. Bunda en önemli etken Selanik sakinlerinin hava kirliliğinden yakınarak, yerel yöneticilerden fabrikaların kent dışında inşa edilmelerini ısrarla talep etmeleri olmuştur. ${ }^{36}$

Selanik örneğinde olduğu gibi şikayet mekanizmasıyla yerel yönetimler bazında sonuç alınan örnekler mevcuttur. Bununla birlikte artan şikayetler Osmanlı yönetimini daha kapsayıcı önlemler almaya yöneltmiş ve Osmanlı yöneticilerinin bu konudaki çözüm arayışları fabrikaların inşasına dair nizamnameler hazırlamak, yer seçimi ile ilgili kısıtlamalar getirmek ve ruhsat alımını merkezileştirerek denetimi artırmaya çalışmak şeklinde ortaya çıkmıştır. Zaman zaman ise fabrikaların kapatıldığı dahi olmuştur. ${ }^{37}$

\section{Fabrikaların İnşasına Dair Hazırlanan Nizamnameler ${ }^{38}$}

19. yüzyılın ilk yarısı devletin zanaat ölçeğinden fabrikaya geçiş sürecini bizzat üstlendiği, sarayın ve yeni kurulan ordunun ihtiyaçlarını karşılamak üzere, ağırlıklı olarak İstanbul ve yakın çevresinde, büyük ölçekli sanayi tesislerinin kurulduğu bir dönem iken, yüzyılın ikinci yarısında özel sermaye ile kurulan fabrikaların teşvik edildiği, devletin daha çok düzenleyen ve denetleyen olarak kendini konumlandırdığı görülmektedir. Nitekim

\footnotetext{
${ }^{32}$ Bu konudaki belgeler: Galata'da bir makarna fabrikasından çıkan dumanın yangın zannedilerek halkın toplandığı, BOA, Ylldız/ Mütenevvi Maruzat (Y.MTV.), 80/220, M. 12.08 .1893 (H.29.M.1311) ; Feshane dökümhanesinin bacasından çıkan dumanın yangın alameti olduğunun sanıldığı, BOA, Yıldız/ Askeri Maruzat (Y.PRK.ASK.), 254/14, M. 02.02.1908 (H. 29.Z.1325).

${ }^{33}$ Tiğginçe Oktar- Hamdi Genç, "Osmanlı İstanbulu'nda Haliç ve Çevresinde Kirlilik Sorunu”, Haz. Süleyman Faruk Göncüoğlu, Dünü ve Bugünü ile Haliç Sempozyumu 22-23 Mayıs 2003, Kadir Has Üniversitesi Yayınları, İstanbul 2004, s. 586.

${ }^{34}$ Tanju Sarı, Osmanlı İmparatorluğu'nda Sanayileşme Çerçevesinde İstanbul'daki Fabrikaların Oluşum ve Geliş̧imi, (Marmara Üniversitesi Sosyal Bilimler Enstitüsü Yayınlanmamış Doktora Tezi), İstanbul 2006, s. 99.

${ }^{35}$ Uğur Tanyeli, "Transfer of Western Urban Planning Concepts and the Techniques to Turkey (1718-1840)", Ed. Ekmeleddin İhsanoğlu, Transfer of Modern Science and Technology to the Muslim World, IRCICA Yayınları, İstanbul 1992, s. 346.

${ }^{36}$ Donald Quataert, "Fabrika Bacalarından Tüten İlk Dumanlar", Haz. Gilles Veinstein, Selanik 1850-1918. Yahudilerin Kenti ve Balkanlar'in Uyanışı, İletişim Yayınları, İstanbul 2001, s. 192.

${ }^{37}$ Konuyla ilgili belge: Mutasarrıf olduğu susam yağı fabrikasının yaydığı duman ve buharın civar halkının sağlığını tehdit ettiği gerekçesiyle haksız yere ve erbab-1 garazın çabaları neticesinde kapatıldığından ve saireden bahisle İzmir'de Karataş'ta mukim Romanya tebaasından tüccar Todori tarafindan verilen arzuhal üzerine icra olunacak muamele, BOA, Bab-ı Ali Evrak Odası (BEO.), 3800/284995, M. 03.09.1910 (H. 27.Ş.1328).

38 Didem Boyacioğlu, "Tanzimat'tan Cumhuriyet'e Osmanlı Fabrika Yapılarının İnşasına Dair Yapılan Düzenlemeler”, Uluslararası Sosyal Araştırmalar Dergisi, C.8, S. 38, 2015, s. 471-486.
} 
fabrikaların inşasına dair ulaşılabilen en erken tarihli nizamname hava kirliliğinin önlenmesi amacıyla hazırlanmış 1861 tarihli bir tasarıdır. Diğer nizamnameler ise "sabit buhar makinelerine dair nizamname (1862)", "Memalik-i Şahane'de (Osmanlı ülkesi) fabrikalar tesisine dair nizamname layihası (tasarıs1) (1886)", "fabrikalar nizamnamesi (1906)" ve "mahallerde kullanılan buhar kazanları, buhar hazneleri ve motorlar hakkında nizamname layihası (1913)"dır. ${ }^{39}$

Nizamnamelerin hazırlanması buhar makinelerinin kullanımın yaygınlaşması ile yakından ilgili görünmektedir. Buhar makinesinin Osmanlı topraklarına girdiği tarih tam olarak bilinmemektir. Yine de bu konuda yapılmış bazı erken girişimlerle ilgili bilgi ve belgeler mevcuttur. 1798 yılında, Mühendishane halifelerinden aslen bir İngiliz olan Mühendis Selim Efendi, tersanede inşa edilmekte olan "büyük havuz" da kullanılmak üzere, buhar gücüyle çalş̧an bir tulumba (tulumba-i nariye) alması için İngiltere'ye gönderilmiş ve burada üç yıl kalmıştır. ${ }^{40}$ Buhar makinesinin alımıyla ilgili bu teşebbüsler devam ederken, 1800 yılında Tophane'de bir vapurhane binasının da inşasına başlandığı anlaşılmaktadır. ${ }^{41}$ Bununla birlikte, gerek arşivdeki, gerekse literatürdeki bilgilerden, buhar makinesinin sanayide kullanımının 1830'lardan sonra arttı̆̆ 1 ve diğer birçok yenilikte olduğu gibi öncelikle devlet yapılarında gerçekleştiği anlaşılmaktadır. Arşiv belgeleri içinde, 1833-1839 yılları arasında, "Tophane-i Amire için inşa edilen vapurhane" ve "Dolmabahçe'de inşa edilmekte olan Tüfekhane-i Amire vapurhanesi" ile ilgili olarak çok sayıda belge bulunmaktadır. ${ }^{42}$ Tersanenin saray alanından kazandığ 1 bölgede, 1834 yılında kurulan haddehanede buharlı makineler kullanıldığ 1,1835 yılında kurulan bıçkıhanenin ise buharla işletildiği bilinmektedir. ${ }^{43} 1840$ ' 1 y yllarda ise, Feshane ve Beykoz Deri ve Kundura Fabrikası buharla üretime geçmiş, Bursa'da ilk buharlı ipek fabrikası olan Harir Fabrika-i Hümayunu kurulmuştur. ${ }^{44} \mathrm{Bu}$ dönemden sonraki arşiv belgelerinde ise, "vapur değirmenleri" kurulması için yapılan teşebbüslerin dikkat çekici bir şekilde arttığı görülmektedir. ${ }^{45}$

Buhar makinesi kullanımının İstanbul ve diğer şehirlerde yaygınlaşması ile devletin konuyla ilgili bazı düzenlemeler yapması zorunlu hale gelmiştir. Bu amaçla, 1861 tarihinde Meclis-i Maâbir tarafından "sıhhat-i umumiyye için gerekli havayı değiştirdikleri" gerekçesiyle İstanbul'daki fabrika ve vapurların nizam altına alınmasını öngören 17 maddelik bir nizamname layihası hazırlanmıştır. Meclis-i Ali-i Tanzimat'ta olumlu ve olumsuz yönleri görüşülerek karara bağlanan layihanın tam metnine ulaşılamamış olmakla birlikte, meclisin görüşlerini içeren ve Ticâret Nezâret-i Celilesi'yle Zabtiye Müşîriyeti'ne yazılmış, 1861 tarihli tezkere konuyla ilgili önemli bilgiler içermesi bakımından önemlidir. ${ }^{46}$

\footnotetext{
39 Ele alınan düzenlemeler fabrikaların genelini kapsayan ve fabrikaların inşa edildikleri yere, kent içindeki konumlarına veya mekansal özelliklerine ilişkin bilgiler içeren düzenlemelerdir.

${ }^{40}$ Mustafa Kaçar- Tuncay Zorlu- Burak Barutçu- Atilla Bir- C.Ozan Ceyhan- Aras Neftçi, İstanbul Teknik Üniversitesi ve Mühendislik Tarihimiz, Ed. Mehmet Karaca, İTÜ Vakfi Yayınları, İstanbul 2012, s. 125.

${ }^{41}$ BOA, Cevdet/ Askeriye (C.AS.), 628/26515, M. 09.10.1800 (H.20.CA.1215).

${ }^{42}$ BOA, Hatt-ı Hümayun (HAT), 594/29129, M.19.05.1833 (H.29.Z.1248); BOA, HAT, 596/29276, M. 09.05.1834 (H.29.Z.1249); BOA, HAT, 585/28780, M. 26.03.1838 (H. 29.Z.1253); BOA, C.AS., 282/11743, M. 01.01.1839 (H.15.L.1254) Ayrıca bkz. Edward C. Clark, "Osmanlı Sanayi Devrimi”, Ed. Ekmeleddin İhsanoğlu, Osmanlılar ve Batı Teknolojisi Yeni Araştırmalar, Yeni Görüşler, İstanbul Üniversitesi Edebiyat Fakültesi Yayınları, İstanbul 1992, s. 39.

${ }^{43}$ Tayyibe Gül Köksal, Haliç Tersanelerinin Tarihsel-Teknolojik Gelişim Süreci ve Koruma Önerileri, (İstanbul Teknik Üniversitesi Fen Bilimleri Enstitüsü Yayınlanmamış Yüksek Lisans Tezi), İstanbul 1996, s. 26.

${ }_{44}$ Önder Küçükerman, Geleneksel Türk Dericilik Sanayii ve Beykoz Fabrikası, Sümerbank, İstanbul 1988, s. 150.

${ }^{45}$ BOA, Cevdet/ İktisat (C.IKTS.), 27/1346, M. 25.09.1841 (H.08.Ş.1257); BOA, Iradeler/ Dahiliye (İ.DH.), 116/5881, M. 03.02.1846 (H.06.S.1262); BOA, Cevdet/ Maliye (C.ML.), 448/18110, M. 06.10.1846 (H. 15.L.1262).

${ }^{46}$ BOA, Sadaret/ Mühimme Kalemi Evrakı (A.MKT.MHM.), 206/13, M. 16.01.1861 (H. 04.B.1277).
} 
Tezkereye göre hazırlanan layiha Avrupa'daki usul ve nizamata uygun bulunmuş ve Devlet-i Aliyye tarafından şimdiye kadar bu hususta kararlaştırılmış herhangi bir usul olmadığı, dolayısıyla zorluklarına rağmen gerektiği zaman müracaat edilecek bir nizamname tasarısının yerinde bir çalışma olduğu belirtilmiştir. Bununla birlikte, asıl endişe edilen noktanın hava kirliliğinden ziyade fabrikalardan dolayı meydana gelebilecek yangın vb. afetler olduğu anlaşılmaktadır. Fabrikaların, meskenleri içine alan sahil ve mevkilerde çoğalmasının rahatsızlığa ve ahalinin şikayetlerine yol açacağı düşünülmüş, İstanbul ve etrafındaki binaların çoğunluğunun ahşap olduğu düşünülünce tehlikenin tamamen ortadan kaldırılması için mahalleler ve meskenler arasında buhar ile imalat yapan fabrikaların kurulmasının yasaklanması istenmiştir. Fabrikaların tesis edileceği mevkinin her türlü tehlikeden uzak olması ve Nezaret-i Celile ile Zaptiye tarafından muayene edilip uygun görülmesi önerilmektedir.

Söz konusu layiha fabrikaları nizam altına almayı öngören ilk tasarı olması açısından önemlidir. Ertesi sene (M. 07.06.1862) içeriği geliştirilen tasarı "sabit vapur makinelerine mahsus nizamname" başlığı altında, üç bölüm ve on sekiz maddeden oluşan bir yönetmelik haline getirilmiş ve onaylanarak yürürlüğe girmiştir. ${ }^{47}$

1870'li yıllar devletin fabrika kurmak yerine özel sektörün fabrika kurmasını kolaylaştıracak önlemler aldığı bir dönem olmuştur. Yeni kurulacak fabrikalar için gerekli makine ve aletlerin gümrüksüz ithali, üretilen malların iç ve dış gümrüklerden muaf olarak satılması ve en önemlisi şahısların fabrika kurmaları için tanınan imtiyazlar sayesinde, 1880 'lerden sonra özel teşebbüse ait fabrikaların sayısında ciddi bir artış görülmektedir. ${ }^{48} \mathrm{Bu}$ durum fabrikaların inşasına dair o tarihe kadar yapılan düzenlemelerin yetersiz kalmasına neden olmuş ve daha kapsamlı bir nizamnamenin hazırlanmasına ihtiyaç doğmuştur. 28.12.1886 tarihli, "Memalik-i Şahane'de fabrikalar tesisine dair nizamname layihası" bu amaçla hazırlanmış bir tasarı olmalıdır. ${ }^{49}$ Bab-1 Ali Tercüme Odası'ndan, Mütercim Konstatin $^{50}$ tarafından tercüme edilmiş olduğu anlaşılan nizamname yedi bölüm ve yetmiş beş maddeden oluşmaktadır. Bölümler, fabrika tesis etmek için gerekli izinlere, fabrikaların tesis edilecekleri mevkiye, fabrikaların inşasına, sağlığa aykırı addolunan tesisler için konulan şartlara, iş̧̧ilerin çalışma saatlerine ve cezalara ilişkin bilgileri içermektedir. Nizamnamenin yürürlüğe girip girmediği bilinmemektedir. Ancak, 1890 yıllarına ait ruhsat başvurularında hala 1862 tarihli "sabit buhar makineleri nizamnamesi"ne uygun olma koşulunun arandığı görüldügüne göre tasarı aşamasında kalmış olmalıdır. ${ }^{51}$

20. yüzyıl başlarında gaz veya petrolle işleyen makinelerin kullanımının artması ile birlikte fabrikalarla ilgili düzenlemelerin kapsamının bu tür işletmeleri de içerecek şekilde genişletilmesi ihtiyacı doğmuştur. 1906 tarihli nizamname tasarısı "fabrikalar nizamnamesi" başlı̆g 1 altında "fabrikaların tesisine dair genel hükümler" ile "etrafa rahatsızlık veren fabrika ve destgahların (tezgah) tasnifi” ni içermektedir. "Tüccar kazganlarıyla (kazan), gaz ve petrol

\footnotetext{
47 “Sabit Buhar Makinelerine Dair Nizamname”, Düstur, Birinci Tertip C. 2, Matbaa-yı Amire, Dersaadet 1872, s. 441-445.

${ }^{48}$ Ekmeleddin İhsanoğlu, “Osmanlı İmparatorluğu'nda Bilim, Teknoloji ve Sanayide Modernleşme Gayretleri” Haz. Feza Günergun, Osmanlı Bilimi Araştırmaları II, İstanbul Üniversitesi Edebiyat Fakültesi Yayınları, İstanbul 1998, s. 20.

${ }^{49}$ BOA, Hariciye Nezareti/ Tercüme Odast (HR.TO.), 478/24, M. 28.12.1886 (H. 01.R.1304)

${ }^{50}$ Belgenin üzerinde tercümeyi yapanın isminden başka bir bilgi bulunmadığından, tercümesi yapılan tüzüğün hangi ülkeye ait olduğu anlaşılamamıştır. Ancak, tüzüğün maddeleri içerisinde geçen "Boğaziçi, İstanbul, Memalik-i Şahane" gibi sözcükler, söz konusu belgenin yalnızca bir çeviriden ibaret olmadığını, aksine uyarlanmış bir metin olduğunu düşündürmektedir.

${ }^{51}$ BOA, Ticaret, Nafia, Ziraat, Orman, Meadin Nezaretleri/ Heyet-i Fenniye (T.HFN.), 657/46, M. 18.05.1891 (H. 09.L.1308).
} 
ile işleyen muharriklere (hareket ettiren) dair nizamname" başlıklı ikinci bölüm ise, "genel hükümler", "ticari kazganlar hakkında tedbirler", "bir mahalde daimi surette kalacak olan buharlı kazganların tesisi", "lokomobil kazganlar", "gaz veya petrolle işleyen muharrikler", "buhar kazganları ile gazlı ve petrollü muharriklerin kullanımına dair nizamnameye aykırı hareket edenlere verilecek cezalar" başlıklı altı kısımdan meydana gelmektedir.

$\mathrm{Bu}$ konuda yapılan düzenlemelerin içeriğinin geliştirilerek yürürlüğe sokulması ise 1913 tarihli nizamname ile mümkün olabilmiştir. Vapur vb. deniz nakil araçları dışında, mahallerde kullanılan buhar kazanları, buhar hazneleri, lokomobil buhar kazanları ve motorlar hakkındaki nizamname, Nizamname Sanayi İdaresi'nce diğer ülkelerde yürürlükte olan yönetmelikler dikkate alınarak kaleme alınmış ve gerekli düzeltmeler Şura-yı Devlet tarafından yapılmıştır. ${ }^{52}$ Nizamnamenin ilanından önce tesis olunmuş olan tüm buhar makinesi ve motorların nizamnameye uygun hale getirilmesi için bir sene süre tanınmıştır. Ancak bu süre savaş nedeniyle fabrikaların büyük çoğunluğunun kapanmış olması, açık bulunanların ise askeri ihtiyaçlar için işlemekte olduklarından gerekli tadilat ve muayeneyi yaptıramamaları, zaten bu hükmü uygulayacak olan fen memurlarının bazı vilayetlerde silah altına alınmış olması, gerekli olan alet edevatın Avrupa'dan satın alınması ve temin edilmesi konusundaki imkansızlıklar gerekçe gösterilerek, 09.02.1915 tarihli bir ek madde ile bir sene daha uzatılmıştır. 15.02.1916 tarihinde ise verilen süre dolmuş olmasına rağmen daha önce öne sürülen olumsuz koşullar geçerliliğini koruduğu için tanınan sürenin savaş bitiminden 6 ay sonrasına kadar uzatılmasına karar verilmiştir. ${ }^{53}$

Ele alınan düzenlemelerden 1862 y1lında hazırlanan "Sabit buhar makinelerine dair nizamname" ile 1913 yılında hazırlanan "Mahallerde kullanılan buhar kazanları, buhar hazneleri ve motorlar hakkında nizamname" dışındaki tüm nizamnameler, birer "layiha" yani tasarı niteliğinde olup, yürürlüğe geçtiklerine dair bir belgeye ulaşılamamıştır. Nitekim dönemin kanun ve nizamnamelerinin toplandığ 1 . Tertip Düstur'da (1839-1908) sadece sabit buhar makinelerine dair nizamnamenin kaydı bulunmaktadır.

Başbakanlık Osmanlı Arşivi'ndeki belgeler arasında yer alan "Fabrikaların kurulum şekilleri ve yerlerine ait olup Şura-yı Devlet'te incelemede bulunan nizamiye layihasının sonuçlandırılması isteği”" başlıklı 1919 yılına ait belgede, 1913 yılında, Sanayi Müdür-i Umumisi'nin başkanlığı altında, Şehremaneti ile Harbiye ve Adliye Nezaret-i Celileri'nden birer memur, Ticaret Odası'ndan bir yetkili ve şehrin sanayi erbabı bazı kişilerinden oluşan bir komisyon tarafından hazırlanmış, "Fabrikaların suret-i ihdasına (doğru yolu gösterme) dair nizamname" başlıklı bir tasarının adı geçmektedir. ${ }^{54}$ Söz konusu nizamname tasarısı 1913 yılında mahallerde kullanılan buhar kazanları ve motorlarla ilgili yürürlüğe giren nizamnameden farklı bir düzenleme olmalıdır. Belgeden, sınırları Şehremaneti tarafından kararlaştırılan ve fabrikaların inşasının yasak olduğu yerleri gösteren bir haritanın da bu nizamnameye eklenmiş olduğu anlaşılmaktadır. Şehremanetine fabrika kurmak için yapılan başvuruların son zamanlarda iyice arttığı gerekçesiyle, Şura-yı Devlet'te görüşülmekte olan layihanın bir an önce sonuca bağlanması istenmektedir. Gerek nizamnameye, gerekse ekindeki haritaya ulaşılamamıştır. 1921 yılına ait bir başka belge ise konunun hala tartışıla geldiğini göstermektedir. Belgede, 1913 tarihinde yürürlüğe giren nizamname ${ }^{55}$ ile birlikte eskiden geçerli olan nizamname lağvolduğu için, "hudud-1 memnu"nın da ortadan kalktığı ve eskiden

\footnotetext{
${ }^{52}$ BOA, Iradeler/ Dosya Usulü (İ.DUIT.), 19/3, M. 28.06.1913 (H. 23.B.1331).

${ }^{53}$ BOA, İ.DUİT., 19/1, M. 13.05.1916 (H.10.B.1334); BOA, İ.DUİT., 19/2, M. 11.03 .1915 (H.24.R.1333).

54 BOA, Dahiliyel Umur-l Mahalliye-i Vilayat Müdüriyeti Belgeleri (DH.UMVM.), 78/8, M.28.10.1919 (H.03.S.1338).

55 Bahsi geçen nizamname "Mahallerde kullanılan buhar kazanları, buhar hazneleri ve motorlar hakkında nizamname" olmalıdır.
} 
yasaklı olan bu mahallerde fabrika tesisi için birbiri ardısıra başvurular geldiği anlatılmaktadır. Aynı tarihlerde Boğaziçi'nde fabrika kurulmasının önlenmesi için bir layiha hazırlanması gerektiği Meclis-i Vükela'ca karara bağlanmıştır. ${ }^{56} \mathrm{Bu}$ tarihten sonraki gelişmeler ise takip edilememiştir.

\section{Yer Seçimi ile İlgili Kısıtlamalar}

Osmanlı yönetimi "sanayi bölgeleri” planlamak yerine, hazırladığı nizamnamelerle "sanayinin yasak olduğu bölgeleri” tanımlamıştır. Boğaz’ın iki yakası, Haliç ve Marmara kıyılarını yani İstanbul'un suya kenarı olan mahallelerini içine alan bir hudut tanımlanmaktadır. Bu hudut, 1861 tarihli hava kirliliğinin önlenmesi için olan nizamname layihasında "Anadolu tarafında Serviburnu'ndan Fenerbahçe'ye, Rumeli tarafında ise Sarıyer'den Arnavutköyü'ne ve aşağısı bir taraftan Boğaziçi ve diğer taraftan Kağıthane, Alibeyköy ve Rami Çiftliği ve Yedikule'den geçen bir kırık çizgi ile bir taraftan dahi denizle sinırlı mahaller" şeklinde tarif edilmiştir. ${ }^{57}$ Hudut dahilindeki mahalle ve meskenler arasında buhar ile imalat yapan fabrikaların kurulması yasaklanmıştır. 1862 yılına tarihlenen "sabit buhar makinelerine dair nizamname" de de fabrikaların inşasının yasak olduğu sınırlar hemen hemen aynı şekilde tariflenmiştir. Buna göre "Boğaz'ın Anadolu tarafinda, Anadolu Feneri'nden başlayıp, sahile Anadolu Hisarı'na, oradan Göksu derelerinin bitiminden Çamlıca'ya ve Kurbağalıdere'den Fenerbahçe Burnu'na kadar, Rumeli tarafında ise, Rumeli Feneri'nden başlayıp yine sahile Büyükdere'ye ve oradan Beyoğlu'na giden cadde ile Kağıthane, Alibeyköy, Rami Çiftliği, Yedikule ve aralarından geçerek Ayastefanos (Yeşilköy) karyesine kadarki kırık çizgi dahilinde" buhar makinesi konulması yasaktır. (Ek 2)

Ancak tarif olunan hudut dahilindeki mahaller aynı zamanda su kenarı olmaları nedeniyle sanayi tesisleri için en çok tercih edilen bölgelerdir. Dolayısıyla yasağın uygulanmasında zorlanılmıştır. 1864 yılında, Meclis-i Maabir, nizamnamenin, Boğaz’ın iki tarafı, Haliç ve Yeşilköy’e kadar olan Marmara kıyılarında, sınırları tarif edilen bölge içerisinde buhar makinesi kullanımını yasaklayan on birinci maddesinin değirmencilere zarar verdiği gerekçesiyle yeniden görüşülmesini istemiştir. ${ }^{58}$ İstanbul'un havasını korumak amacıyla getirilen yasağın, yerli değirmencileri yabancilarla rekabet edebilecekleri araçtan mahrum bıraktığı ve bunun da buğday fiyatlarının artmasına sebep olduğu düşünülmektedir. Bahsi geçen yasak, demiryolları inşası ${ }^{59}$ ile doğal olarak fesholacaksa, bunların inşası zamanını beklemeyerek, adı geçen nizamnameye bir an önce bir madde ilave olunması önerilmiştir. ${ }^{60} \mathrm{Bu}$ ek madde ile nizamnamenin 11. maddesinde belirtilen hudut dahilinde dumanı önlemek şartıyla buhar makinesi kullanımına izin verilmiştir. Nitekim 1862 tarihli bir belgede, inşası istenen fabrika nizamnamenin 11. maddesinde belirtilen yasaklı hudutlar dahilinde kaldığından inşasına izin verilmezken, 1876 tarihli bir başka belgede Karaağaç’ta inşa edilen tuğla fabrikası nizamname hükmünce "hudud-1 memnu" dahilinde bulunduğundan ancak yakacak olarak zeytin çekirdeği kullanmak şartıyla işletilmesine izin verilmiştir. ${ }^{61}$ Bununla birlikte, buhar makinesinin yerleştirileceği mahal sahilhane aralarında veya mahalle içlerinde

\footnotetext{
${ }^{56}$ BOA, Meclis-i Vükela Mazbataları (MV.), 221/254, M. 20.08.1921 (H.15.Z.1339).

${ }^{57}$ BOA, A.MKT.MHM., 206/13.

${ }^{58}$ BOA, Irade/ Meclis-i Vala (İ.MVL.), 520/23374, M. 10.10.1864 (H.09.CA.1281).

59 Onbirinci maddenin tartışıldığ tarihte, Bab-1 Ali, İstanbul'dan başlayarak Edirne'ye, oradan da Balkanlar üzerinden Avrupa'ya ulaşacak olan Rumeli demiryollarının inşası için bir yüklenici firma arayışı içindedir. Sena Bayraktaroğlu, Developments of Railways in the Ottoman Empire and Turkey, (Boğaziçi Üniversitesi Sosyal Bilimler Enstitüsü Yayınlanmamış Yüksek Lisans Tezi), İstanbul 1995, s. 28.

${ }^{60}$ BOA, İ.MVL., 520/23374.

${ }^{61}$ BOA, A.MKT.NZD, 424/66, M. 13.06.1862 (H. 15.Z.1278), BOA, A.MKT.MHM.480/14, M. 07.04.1876 (H.12.03.1293).
} 
olmayacaktır. ${ }^{62}$ Ancak, belirtilen hudut dahilinde olup, nizamnamenin tesis ve ilavesinden önce yapılmış olan fabrikaların, "fomivor" adı verilen duman yakıcı aletten kullanmak suretiyle nizama uygun hale getirilmesine izin verilmiştir. ${ }^{63}$

Her iki nizamnamede de sadece İstanbul için geçerli olan "hudud-ı memnu" belirtilmiş olup diğer şehirler hakkında herhangi bir bilgi bulunmamaktadır. 1886 tarihli "Memalik-i Şahane'de fabrikalar inşasına dair nizamname layihası" ise bu konuya açıklık getirecek şekilde daha genel hükümler içermektedir. Buna göre "İstanbul ve ona bağlı yerler ile nüfusu en az on bin kişi olan şehirlerde fabrika inşasının yasak olduğu bölgeleri gösteren bir harita söz konusu yerin belediyesi tarafindan hazırlanacaktır. Bu bölgeler fabrikalar tesisinin yasak olduğu mahalleri kuşatan cadde ve sokakların isimleriyle anılabilir. Ayrı tutulan bu bölgeler dışında fabrika inşasının kesinlikle yasak olduğu bazı mevkiler de tanımlanmıştır. Bunlar, "baruthaneler, silah ve mühimmat depoları, istihkâmlar ile mülki ve askeri hastaneler, müzeler, büyük okullar, saray ve kasrlar, camiler ve mabedler ${ }^{64 "}$ 'dir. Boğaziçi sahil boyunca ve sahili olan şehirlerde fabrika kurulması ise bazı özel şartlara bağlanmıștır; "Fabrika tesisine ancak fabrika için teklif olunan yere yedi yüz metre mesafede bulunan civar halk tarafindan bu fabrika aleyhine itiraz gelmediği takdirde izin verilebilir. Civar halkın izinleri alındıktan sonra bile resmi izinlerin başlıca şartı dumanın toplanması ve balıkların korunması için lazım gelen en etkili çözümlerin uygulanmasıdır".

Fabrika inşasının kesinlikle yasak olduğu mevkiler 1906 yılında hazırlanan "Fabrikalar Nizamnamesi"nde de yer almaktadır. Buna göre "saray ve kasr-1 hümayunlar ile askeri dairelere bağlı karakollar, kışlalar, hastaneler, cephanelikler, baruthaneler, silah depoları, hapishaneler, mektepler, kale istihkamı ve savunmayla ilgili çeşitli binalar, resmi daireler, belediyeler, mescitler, tekkeler, kütüphaneler ve medreseler civarında" fabrika yapılması yasaktır $^{65}$. Fabrika binasının beden duvarları ile bahsi geçen diğer binalar arasında en az 100 m. mesafe olması şartı konulmuştur.

$\mathrm{Bu}$ konudaki belgeler çeşitlidir. Askeri bölgelere yakın alanlar elbette ki çok önemsenmiştir. Örneğin, bir belgede Bekçiler Müdürü Salim Ağa’nın, 1886 yılında, Dersaadet ve Kale-i Sultaniye'de inşa etmek istediği buz fabrikasının Kale-i Sultaniye'deki istihkamlar açısından bir sorun teşkil etmediği ve Boğaz Muhafızlığı'nın göstereceği yerde inşaatın yapılabileceği belirtilmektedir. ${ }^{66}$ Bir başka belgede ise Vitalis Paşa'nın Fransa tebaasından olan eşi ve ortakları ile birlikte, 1892 yılında, Rumelikavağı ile Kilyos arasındaki bölgede bir şeker fabrikası kurmak için yaptığı başvuruya, yapılan keşif sonunda, bölgenin askeri birliklere yakın ve Boğaz savunması açısından önemli bir yer olması nedeniyle olumsuz cevap verildiği görülmektedir. ${ }^{67}$

Gerek 1876 ve gerekse 1906 nizamnameleri saray, köşk ve kasrların yakınında fabrika kurulmasını yasaklamaktadır. Bu konuda alınan önlemler yine şikayet mekanizması ile

\footnotetext{
${ }^{62}$ Düstur, "Sabit Buhar Makinelerine Dair Nizamname", 1872.

${ }^{63}$ BOA, İ.MVL.520/23374.

${ }^{64} 1855$ yılına ait bir belgeden, nizamnamede ayrıntılı bir şekilde listelenen bu mevkilerin dışında, ziraat alanında fabrika inşasının da yasaklanmış olduğu anlaşılmaktadır. Reayadan Andon'un Maltepe'de yağ fabrikası inşası için yaptığı başvuru sonucunda, fabrika yerinin "zirâ'at ve hırâset (koruma) olunacak mahal” olup olmadığının araştırılması istenmiştir. BOA, A.MKT.NZD.125/54, M. (H.15.04.1271).

${ }^{65}$ Aslında, cami ve mescitler civarında, beş zirâ $(\approx 380 \mathrm{~cm})$ mesafe dahilinde, herhangi bir inşaatın yapılması daha 16. yüzyılda yasaklanmıştır. Abdülkadir Dündar, Arşivlerdeki Plan ve Çizimler Işı̆̆ı Altında Osmanlı İmar Sistemi, XVIII. Ve XIX. Yüzyıl, T.C. Kültür Bakanlığı Yayınları, Ankara 2000, s. 19.

${ }^{66}$ BOA, MV.10/16, M. 19.05.1886 (H.15.Ş.1303).

${ }^{67}$ Mehmet Karayaman, “Osmanlı Devleti'nde Şeker Fabrikası Kurma Teşebbüsleri”, Tarih Incelemeleri Dergisi, C. $X X V$, S.1, 2010, s. 310.
} 
devreye girmektedir. Örneğin, 1892 yılında, Fenerbahçe Çiftehavuz mevkiindeki Emlak-1 Hümayun'a ait tarlada kibrit fabrikası yapımına başlanmış, ancak civar halkın bu alanın gezinti mahalli olduğu ve etrafta çok sayıda köşk bulunduğu gerekçeleriyle yaptıkları şikayet dikkate alınarak mahalin yeniden tetkikine karar verilmiştir. ${ }^{68}$

Konuyla ilgili olarak üzerinde konuşulabilecek dikkat çekici bir başka örnek ise Yıldız sarayının dış bahçesinde yer alan porselen fabrika-i hümayununun saraya yakınlığı göz önüne alınarak başka bir yere taşınması hususunda 1910-16 yılları arasında yapılan yazışmalardır. 18 Ekim 1910 tarihinde Maliye Nazırı'nın fabrikanın başka bir yere taşınması talebiyle sadrazama gönderdiği tezkireye cevaben fabrikanın civardaki köşk ve bahçeye zarar vermeden ifrazının mümkün olup olmadığının araştırılması istenmekte, bu amaçla oluşturulacak heyetin alınan kararı bir rapor ve harita ile padişaha sunması beklenmektedir. Müze-i Hümâyûn müdürü Halil Edhem Bey, Evkaf-1 Hümâyûn tamirat müdürü mimar Kemaleddin Bey ve Hazine-i Hassa müdürü Feyyaz Efendi'den oluşan heyet hazırladığı rapor ve harita ile fabrikanın yerinin Malta Köşkü’ne 70 metre uzaklıkta bulunduğunu, bir duvarla ifrazının mümkün olduğunu ve daha önce kapattırılmış olan kapının tekrar açılarak fabrikaya ayrı bir giriş sağlanabileceğini ifade etmiştir. Planları Vedat Bey tarafından hazırlanan kapının inşası Dimitri Kalfa tarafından yapılmıştır. Fabrikanın taşınması konusu 1914-16 yılları arasında tekrar gündeme gelmiş, hatta bu amaçla Fenerbahçe'de inşasına başlanan fabrika binası tamamlanamamış ve sonuç itibariyle Yıldız çini ve porselen fabrikasının saraya yakın bir mahal olmayıp sadece sarayın bahçesinde yer aldığı ve saray müştemilatından dahi olmadığı kararına varılmıştır. ${ }^{69}$

1918 yılında, Paşabahçe'de, Sultaniye Çayırı diye adlandırılan yerdeki bir kısım arazi Milli İnşaat-1 Bahriye Şirketi tarafından satın alınarak nakliye gemilerine mahsus bir fabrika ve tersane inşasına teşebbüs edilmiştir. Bu teşebbüsle ilgili olarak Dâhiliye Nazırı'nın Sadaret'e yazdığ takrir dönemin Osmanlı yönetici elitinin fabrikaların inşa edileceği yere ilişkin düşüncelerini özetler niteliktedir. ${ }^{70}$ Belgede, fabrikanın kuruluşu için yapılan teşebbüsün ülke için önemi vurgulanmakla birlikte bu çeşit tesislerin örneğin İzmit Körfezi ${ }^{71}$ ve Marmara sahili gibi şehirden uzak mahallerde inşa edilmelerinin gerekliliğinden bahsedilmektedir. Boğaziçi üzerinde hassasiyetle durulan bir konudur. Dahiliye Nazırı'nın tabiriyle "Hava ve letafet-i mevkiiyesiyle meşhur-1 cihan olan ve zarif köyler ve kaşanelerle ve ecnebi seyyahları celb edecek oteller vesair vesait-i temeddün (medenileşme) ile tertibi lazimeden bulunan Boğaziçi'nde" fabrika ve depo gibi müesseselerin inşası devlet tarafından yasaklanmalıdır. Nitekim aynı amaçla 1910 yılında Haliç sahillerinden kömür depolarının kaldırılarak yerlerinin Şehremaneti tarafından istimlak edilmesine ve ruhsatsız olarak çalışan fabrikaların da Yeşilköy sahiline taşınmasına karar verilmiştir. ${ }^{72}$

Osmanlı sanayileşmesi elbette kendi koşulları içinde fakat temelde Batı'ya bakarak gerçekleşmiştir. Dahiliye Nazırı'nın takririnde de bu açıkça görülmektedir. İngiltere, Almanya, Fransa, Belçika gibi sanayi hususunda ileri düzeyde olan ülkeleri örnek gösteren Dahiliye

\footnotetext{
${ }^{68}$ BOA., DH.MKT., 1975/48, M. 22.07.1892 (H.26.Z.1309).

${ }^{69}$ Sinem Serin, Yıldız Çini/Porselen Fabrikası, (İstanbul Üniversitesi Sosyal Bilimler Enstitüsü Yayınlanmamış Yüksek Lisans Tezi), İstanbul 2009, s. 90.

${ }^{70}$ BOA, DH.UMVM.78/8.

${ }^{71}$ İzmit, gerek İstanbul'a yakınlığı ve gerek oldukça işlek bir liman olma özelliğinden ötürü, Tanzimat döneminden itibaren Osmanlı sanayileşmesi içindeki yerini almıştır. İzmit Çuha fabrikası, Hereke kumaş fabrikası gibi yapılar Tanzimat döneminde devlet eliyle kurulmuş sanayi tesisleridir. İstanbul'a kara ve deniz yoluyla bağlı olan İzmit, 1873 yılında, Anadolu-Bağdat demiryolunun ilk etabı olan Haydarpaşa- İzmit hattının açılmasıyla demiryoluyla da bağlanmıştır. Hilal Karavar, Osmanlı'dan Cumhuriyet'e İzmit Çuha Fabrikası 1844-1920, Kocaeli Büyükşehir Belediyesi Kültür Yayınları, Kocaeli 2007, s. 48-49.

${ }^{72}$ Mehmet Sait Türkhan, “19 ve 20. yy’da Haliç’te Çevre Sorunları ve Deniz Kirliliği”, Toplumsal Tarih, S.169, İstanbul 2008, s. 65.
} 
Nazırı, bu ülkelerde kurulacak fabrikaların săglığa zararlı, tehlikeli veya çevreye rahatsızlık verecek şekilde olmaması için bir takım özel şartlar ve hükümler olduğunu, bu çeşit müesseseler için şehrin uygun mahallerinde "menatık-1 sanaiyye" (sanayi bölgeleri) oluşturulduğunu, özellikle Almanya ve Belçika'da fabrika kurmanın Ticaret ve Ziraat Nezaretleri'nden alınacak özel izinlere tabi olduğunu anlatmaktadır. Bu şekilde "sanayi bölgesi" kavramının da artık Osmanlı yönetici eliti tarafından telaffuz edilmeye başlandığı görülmektedir. ${ }^{73}$

\section{Diğer Önlemler}

Hazırlanan nizamnamelerle imalat yapılan mahallerin yerleşim yerlerine olan mesafelerinin de bir kurala bağlanması amaçlanmıştır. Hava kirliliğinin önlenmesi için hazırlanan nizamname layihasında fabrikalar makinenin kuvvetine göre 3 sınıfa ayrılmıştır. Birinci sınıf fabrikaların oluşturdukları tehlike nedeniyle her türlü hane ve içinde destgah (tezgah, işlik) bulunan binadan uzakta inşa edilmeleri öngörülmüştür. İkinci sınıfta yer alanların ise, belli şartlar dahilinde yerleşim yerlerinin yakınında konumlanmasına izin verilmiştir. İçerisine buhar kazanı konulan binanın etrafı muhafaza duvarlarıyla çevrili olmalı ve fabrika yapılarından ayrı bir mahalde yer almalıdır. Bu sayede, bir çeşit makine dairesi oluşturulması istenmektedir. Üçüncü sınıf fabrikaları tanımlayan makinelerin ise haneden sayılan binaların içinde bulunan destgah mahallerine konulmasına bile izin verilmiştir. $\mathrm{Bu}$ fabrikalar en tehlikesiz grup olarak görülmesine rağmen, yine de her türlü koruma tedbirinin alınmış olması ısrarla vurgulanmıştır. Hava kirliliğinin önlenmesi için yerleşim yerlerine yakınlık ile ilgili getirilen kısıtlamaların dışında alınması önerilen bir diğer önlem kullanılan yakıtlar ile ilgili olup, duman vermeyecek yakıt kullanılması veya ocaklardan çıkan dumanı tamamen yakacak bir düzenleme yapılması istenmiştir. ${ }^{74}$

Sabit buhar makinelerine dair nizamname yerleşim yerleri içerisinde bulunan buhar kazanlarının etrafındaki binalar ile ilişkisini düzenlemektedir. Buna göre buhar kazanları ile etrafında bulunan haneler veya yol arasında en azından buhar kazanının kuvvetinin üçte biri kadar mesafe olmalıdır. Bu mümkün olmadığı taktirde en az bir arşın $(\sim 75 \mathrm{~cm})$ kalınlığında "muhafaza duvarı" diye adlandırılan bir duvar inșa olunacaktır. Bu duvarın yüksekliği buhar kazanının en yüksek noktasını, en azından duvar ile kazan arasındaki mesafenin yarısı kadar geçecek ve adı geçen duvar ile buhar kazanı arasında ve keza duvar ile etrafında bulunan binaların müşterek duvarları arasında en azından yarımşar arşın $(\sim 40 \mathrm{~cm})$ boşluk bulunacaktır. Birinci sınıf buhar kazanları ise kapalı bir yere konulup hafif bir çatısı olacak ve bitişiğinde hiçbir bina bulunmayacaktır.

Nizamnamenin üçüncü bölümü on ve on dördüncü maddeler arasını kapsamaktadır. Onuncu madde, "kompodor" ${ }^{75 "}$ diye adlandırılan ve buhar kazanlarının ocaklarında meydana gelen dumanı yok etmeye yarayan aletin kullanımıyla ilgili olup, Dersaadet ve Bilâd-1 Selâse'de (Üsküdar, Galata ve Eyüp semtleri) bulunan fabrikalarda, ya adı geçen alet

\footnotetext{
${ }^{73}$ BOA, DH.UMVM.78/8.

${ }^{74}$ BOA, A.MKT.MHM, 206/13.

75 Osmanlı arşivlerinde, vapur ocaklarındaki dumanı yok etmek üzere icat edilmiş "kompodor" tabir olunan bir aletin vapurlara ve bazı değirmenlere konulması ile ilgili, M.1868 tarihli üç adet belge bulunmaktadır. Nizamnamenin neşrinden altı yıl sonra, konunun hala Şura-yı Devlette tartışlageldiği görülen bu belgelerde, aletin mucidi olarak Lupteri, Tiring ve Petri olmak üzere üç farklı Fransızın adı telaffuz edilmektedir (BOA, Ş.D., 1/3, M. 06.09.1868 (H. 18.Ca.1285); BOA, A.MKT.MHM., 423/85, M. 15.10.1868 (H.27.C.1285); BOA, Ş.D., 2390/11, M. 18.11.1868 (H.02.Ş.1285). Ayrıca bknz. Vahdettin Engin, "Osmanlı'da Çevre Şuuru”, Tarih ve Medeniyet, S.7, 1994, s.35-38.
} 
vasıtasıyla dumanın giderilmesini veya odun ve kok kömüründen fazla duman vermeyecek yakıt kullanılmasını zorunlu hale getirmektedir. ${ }^{76}$

Memalik-i Şahane'de fabrikalar tesisine dair nizamname layihasında sağlı̆g 1 ihlal eden sanayi dalları tanımlanmıştır. Sağlığa zararlı ilan edilen fabrika ve atölye sahipleri gerek buralarda çalışan işçilerin ve gerek çevre ahalinin sağlığını korumak üzere gerekli tüm tedbirleri derhal almaya mecburdurlar. ${ }^{77}$

Türkiye'de sanayinin yer seçiminde çevresel etkileri göz önünde bulunduran yürürlükteki yasa Hıfzısıhha Kanunu'dur. 1930'larda yürürlüğe giren bu yasa sanayileri gruplayarak yerleşim yerlerine mesafesini belirler. ${ }^{78}$ Günümüz Türkiye' sinde sanayinin yer seçimi ile kamu sağlı̆̆ı arasında kurulan bağın yasal çerçevesi ilk olarak 19. yüzyılda Osmanlı fabrika yapılarına ait nizamnamelerle çizilmiştir.

\section{Ruhsat ve Denetim}

Osmanlı yönetimi hazırlamış olduğu nizamnamelerle fabrikaların kuruluşuna ilişkin kentsel ölçekte bazı kurallar getirmeyi amaçlamıştır. Bu nedenle fabrikaların inşasının yasak olduğu yerler veya yerleşim yerleri ile arasında olması gereken mesafeler gibi uyulması zorunlu önemli kıstaslar oluşturulmuştur. Konulan bu kuralların uygulanabilirliğini arttırmak ve denetlemek ise ruhsat konusunda yapilacak yeni düzenlemeleri gerektirmektedir. $\mathrm{Bu}$ dönemde ruhsatsız olarak kurulan ve işletilen fabrikalar Osmanlı yönetimi için önemli bir sorun oluşturmaktadır. ${ }^{79}$ Önlem olarak denetimin arttırılması ve ruhsat alımının bir nizama bağlanarak merkezileştirilmesi hedeflenmiştir.

Dersaadet, Bilâd-1 Selâse ve taşradaki ecnebi tebaadan bazılarının, ikamet ettikleri mahaller içinde veya başka mahallerde, ruhsatsız ve izinsiz olarak fabrika işletmeleri ${ }^{80}$ nedeniyle ahaliden gelen şikayetlerin artması üzerine, 1860 tarihinde, Sadaret'ten ilgili tüm valiliklere gönderilen bir emirname ile ruhsatsız fabrika işletilmesine engel olunmak istenmiştir. Emirnameye göre, bundan böyle fabrikaların kurulması mahalli hükümetin onayı ile ve "nizâmât-1 mer' iyye-i belediyye"ye yani yürürlükte olan belediye nizamnamesine göre gerçekleşecektir. İdarecilerden bu konuda hassasiyet göstermeleri ve ruhsatsız fabrika inşasına kesinlikle müsamaha göstermemeleri beklenmektedir. ${ }^{81}$ Resmi izin almadan fabrika açılamayacağ $\breve{l}_{1}$ hususunun sefaretlere de bildirilmesi istenmiştir. ${ }^{82}$

Fabrikaların ruhsat alımına ilişkin hazırlanan emirnamenin 1860 tarihli "Tahrir-i nüfus ve emlak talimnamesi" ile aynı dönemde yayınlanmış olması ilginçtir. Talimnamenin "mimariye

\footnotetext{
${ }^{76}$ Düstur, "Sabit Buhar Makinelerine Dair Nizamname”, 1872.

${ }^{77}$ BOA, HR.TO., 478/24

${ }^{78}$ İlhan Tekeli, Sanayi Toplumu İçin Sanayi Yazıları, Tarih Vakfı Yurt Yayınları, İstanbul 2010, s. 53.

${ }^{79}$ Bu konudaki arşiv belgelerinden bazıları şöyledir: Fransa tebaasından Şarl Boniko'nun Tekirdağ'da izinsiz olarak inşa etmekte olduğu müskirat fabrikasına mani olunması, BOA, HR.MKT.173/67, M. 17.01.1857 (H. 21.Ca.1273); Fransalı tacir Kova'nın Rodos ceziresinde izinsiz olarak ipek fabrikası inşa edemeyeceği, BOA, HR.MKT.195/82, M. 27.06.1857 (H.05.Za.1273); İngiltere tebaasından Ari isimli şahsın Adapazarı’nda ruhsatsız olarak çalıştırdığı hızar fabrikasının kapatılması, BOA, A.MKT.MHM. 257/44, M. 08.03.1863(H.17.N.1279).

${ }^{80}$ Özel teşebbüsün fabrika kurma girişimlerinde gayrimüslimler ve yabancılar ön sırayı almaktadır. Ancak yabancı tabiyetinde olanların Osmanlı topraklarında emlak edinme hakkı 1867 yılına kadar olmadığından çoğu zaman önce arazi alınıp fabrika kurulmuş, sonra ruhsat istenmiştir. Hatta bazı durumlarda şikayet olmadığı sürece ruhsatsız olarak kurulan fabrikaların uzun süre işletilmeye devam edildikleri görülmektedir. Sefer Şener, "Osmanl Sanayileşme Süreci ve Bu Süreçte Özel Girişimin Rolü”, Dokuz Eylül Üniversitesi Sosyal Bilimler Enstitüsü Dergisi, C. 9, S.3, 2007, s. 73.

81 BOA, Sadaret/ Umum Vilayat evrakl (A.MKT.UM.), 442/21, M. 13.12 .1860 (H. 29.Ca.1277); BOA, A.MKT.UM., 436/56, M. 15.11.1860 (H.01.Ca.1277).

${ }^{82}$ BOA, A.MKT.NZD., 341/86, M. 07.02.1861 (H. 26.B.1277).
} 
rüsumu" başlıklı bölümünde klasik Osmanlı düzeninde mimarbaşıdan alınan bina yapım izni ve ruhsat konusunun yeniden düzenlenmesi söz konusudur. ${ }^{83}$ Fabrikaların ruhsat alımı ile ilgili yapılan düzenlemeler de aynı çerçeve içerisinde değerlendirilmeli ve kentin gelişimini denetlemek arzusunda olan siyasi otoritenin modern denetimin örgütlenmesi için verdiği uğraşların bir parçası olarak ele alınmalıdır.

\section{Ruhsat Alımı ve Gerekli İzinler}

1862 tarihli "sabit buhar makinelerine dair nizamname" den önce fabrikaların kurulması, ruhsat alımı ve gerekli izinlerle ilgili özel bir nizamname olmadığı anlaşılmaktadır. Daha erken tarihli olan "hava kirliliğinin önlenmesi için nizamname layihası"nda ise ruhsat alımıyla ilgili herhangi bir bilgi bulunmamaktadır. ${ }^{84}$ Diğer tüm nizamnamelerde, ruhsat başvurusunda başvuru sahiplerinden fabrikayla ilgili bilgileri içeren bir dilekçe ile fabrika ve etrafındaki yapıları gösteren 1/200 ölçekli bir harita istenmektedir. Dilekçenin içeriği, 1862 tarihli nizamnamede, kazanın buhar basıncı, mevkisi, yakıtın cinsi ve ne tür imalat yapılacağı ile ilgiliyken, 1888 ve 1906 tarihli nizamnamelerde fabrikanın yeri, imalatın türü, kullanılacak aletler ile bu imalattan doğabilecek zararların bertaraf edilebilmesi için alınacak önlemlerin de dilekçede açıkça belirtilmesi istenmektedir. ${ }^{85}$ Dilekçeyle birlikte istenen harita tüm nizamnamelerde benzer şekilde tarif olunmakla birlikte, sadece 1906 tarihli nizamnamede, fabrikada kullanılacak alet ve edevatın da haritada gösterilmesi beklenmektedir.

Nizamnamelerde ruhsat başvurusunun yapılacağı makam ve usul farklı şekillerde tarif edilmiştir. Bununla birlikte 1888-1893 yılları arasında yapılmış ruhsat başvuruları incelendiğinde yapılan başvurulardan çok net bir işleyiş olduğunu çıkarmak mümkündür. Buna göre, İstanbul ve taşrada iki farklı uygulama olduğu görülmektedir.

İstanbul'da müteşebbis, öncelikle, bir dilekçe ve fabrika ve yakın çevresini gösteren bir harita ile birlikte Ticaret ve Nafia Nezaret-i Celilesi'ne ruhsat almak talebiyle başvurmaktadır. $\mathrm{Bu}$ dilekçede fabrikanın yeri, imalatın türü, müteşebbisin ismi ve ikamet ettiği yer mutlaka belirtilmektedir. ${ }^{86}$ Eğer fabrikanın inşa edileceği yer 1862 tarihli nizamnamede tarif edilen sınırlar (hatt-1 memnu) içindeyse müteşebbisten ayrıca kazandan çıkan dumanı komodor ${ }^{87}$ âletiyle imhâ etmeyi veya kok kömürü kullanmayı tahaattüt eden bir beyanname alınmaktadır. ${ }^{88} \mathrm{Bu}$ şekilde Nezaret'e gelen başvuru dosyası Nezaret fen müşavirliğine havale edilmektedir. Burada, inşa edilmesi düşünülen fabrikanın 1862 nizamnamesinde belirtilen "hatt-1 memnûa" (yasak sınırlar) dahilinde olup olmadığı kontrol edilmektedir. Fabrikanın tesisinde mevki açısından başka bir mahzur olup olmadığının araştırılması için dilekçe, harita ve diğer belgelerden oluşan başvuru dosyası Şehremaneti'ne gönderilmektedir. ${ }^{89}$ Söz konusu fabrikanın hatt-1 memnu içinde ya da dışında olması bu uygulamayı değiştirmemektedir. ${ }^{90}$ Şehremaneti'nde gerekli inceleme yapıldıktan sonra fabrika yapılacak mahal ile etrafindaki

\footnotetext{
${ }^{83}$ İlhan Tekeli- Selim İlkin, Cumhuriyet'in Harcı: Modernitenin Altyapısı Oluşurken, İstanbul Bilgi Üniversitesi Yayınları, İstanbul 2004.

${ }^{84}$ BOA, A.MKT.MHM., 206/13.

${ }^{85}$ Düstur, "Sabit Buhar Makinelerine Dair Nizamname", 1872; BOA, HR.TO.478/24; BOA, Ticaret, Nafia, Ziraat, Orman, Meadin Nezaretleri Defterleri (T.d.), 88, M. 16.12.1906 (H. 29.L.1324).

${ }^{86}$ BOA, Dahiliye/ İdare (DH.ID.), 107/60, M. 24.05 .1894 (H. 19.Za.1311).

${ }^{87}$ Söz konusu aletin belgelerde farklı söylenişleri olduğu görülmektedir: “......müsted'î-i merkûm ise iş bu fabrikaya “kompodor” yani âkilü'd-duhân (duman yiyen) aleti vaz' edeceğini beyân eylemekde...” (BOA, T.HFN.657/46). Bir başka belgede, fabrikaların, "fomivor" adı verilen duman yakıcı aletten kullanmak suretiyle nizama uygun hale getirildiği anlatılmaktadır (BOA, İ.MVL.520/23374).

${ }^{88}$ BOA, T.HFN.661/49, M. 22.05.1893 (H. 06.Za.1310).

${ }^{89}$ BOA, T.HFN.657/46.

${ }^{90}$ BOA, T.HFN.657/91, M. 20.10.1891 (H. 16.Ra.1309).
} 
binaların 1/200 ölçekli haritasının onaylanıp Nezaret'e gönderilmesi gerekmektedir. ${ }^{91}$ Sonuç olarak, İstanbul'da bir fabrikanın kurulup kurulmaması Şehremaneti’nin yetkisi ve takdiri dahilinde gerçekleşmektedir. ${ }^{92}$

Taşrada ise öncelikle müteşebbis dilekçe ve haritasını bulunduğu yere göre vilayete veya mahalli idareye teslim etmelidir. Dilekçede fabrikanın yeri, imalatın türü, müteşebbisin ismi ve ikamet ettiği mahal gibi bilgilerin yanı sıra kazanın kaç metreküp hacminde olduğu ve kaç derece basınç ile işleyeceğinin de belirtilmesi istenmektedir. ${ }^{93}$ Bazı dilekçelerde ise kazanda kullanılacak yakacak dahi belirtilmiştir. ${ }^{94}$ Teslim edilen belgeler vilayette Meclis-i Belediye ve Meclis-i İdare-i Vilayet, diğer yerlerde ihtiyar meclisi tarafından değerlendirilip, gerekli tahkikat yapıldıktan sonra ilgili makama sonucu bildiren bir izin yazısı yazılmaktadır. Söz konusu meclisler, aynı zamanda, fabrika ve yakın çevresini gösteren haritanın onaylanmasından da sorumludurlar. ${ }^{95}$ Eğer fabrikanın yapılması planlanan alan devlet arazisi ise fabrika tesisi için "irade-i seniyye" yani padişahın izni de istenmektedir. ${ }^{96} \mathrm{Bu}$ durumda Nezaret ile Sadaret arasında çeşitli yazışmalar gerçekleşmektedir. ${ }^{97}$ Eğer fabrikanın inşa edileceği yer kale veya surların yakınında veya askeri bir bölge içinde ise tahkikatı yapan komisyonun, konuyla ilgili olarak askeriyenin de görüşünü alması gerekmektedir. ${ }^{98}$

Taşraya ait ruhsat başvurularında İstanbul'dakilerden farklı olarak fabrikaya alınacak alet ve edevat yani fabrikanın "levazım-1 ibtidâiyyesi" ile kazanın atmosfer ve teferruatını içeren bir defter veya beyannamenin de başvuru esnasında istenen belgeler arasında olduğu görülmektedir. ${ }^{99}$ Ticaret ve Nafia Nezaret-i Celilesi'ne gönderilen dosya Nezaret fen müşavirliğine havale edilir ve gerekli tahkikatı yapılarak hazırlanan ruhsatname sahibine teslim edilir. ${ }^{100}$

Yapılan bu çalışmalar kentin gelişimini denetlemek arzusunda olan siyasi otoritenin modern denetimin örgütlenmesi için verdiği uğraşların bir parçası olarak görülmelidir. Bununla birlikte ruhsat alımına ilişkin tüm bu bürokratik işlemler ve özellikle taşraya ait ruhsat başvurularının merkezin onayına sunulması, süreci uzatan uygulamalar olmuş ve dönem yazarları tarafından sanayileşme ve iktisadi gelişme açısından birer engel olarak görülmüştür. ${ }^{101}$

\section{Sonuç}

Osmanlı yönetiminin fabrikaların kurulması ile ilgili kentsel ölçekte aldığı tüm kararların temel motivasyonunun "kamu sağlı̆̆1" olduğu söylenebilir. 1840’lı yıllardan sonra sayıları hızla artmaya başlayan fabrikaların kentte yarattı̆̆ 1 başlıca sorunlar, fabrika bacalarından çıkan duman, bazı imalathanelerin sebep olduğu kötü kokular, zaman zaman çıkan yangınlar veya meydana gelen patlamalar ile kömür depolarının yarattığı kirliliktir. Bu konuda yapılan şikayetlere ilişkin arşivde çok sayıda belge mevcuttur. Klasik dönem Osmanlı bürokrasisinin

\footnotetext{
${ }^{91}$ BOA, T.HFN.661/49.

${ }^{92}$ BOA, DH.UMVM.78/8.

${ }^{93}$ BOA, T.HFN.661/7, M. 16.03.1893 (H. 27.S.1310)

${ }^{94}$ BOA, T.HFN.659/84, M. 05.09.1892 (H. 12.S.1310); BOA, T.HFN.664/7, M. 13.01 .1894 (H. 06.B.1311).

${ }^{95}$ BOA, T.HFN.658/10, M. 09.11.1891 (H.06.R.1309); BOA, T.HFN.661/7.

${ }^{96}$ BOA, T.HFN.659/31, M. 26.03.1892 (H. 26.Ş.1309).

${ }^{97}$ BOA, T.HFN.660/4, M. 04.10.1892 (H. 12.Ra.1310).

${ }^{98}$ BOA, T.HFN.661/7.

${ }^{99}$ BOA, T.HFN.658/10.

${ }^{100}$ BOA, T.HFN.661/3, M. 02.03.1893 (H. 13.Ş.1310).

${ }^{101}$ Cenap Şahabettin gibi dönem yazarlarının da fabrika açmak için uzun bir formalite sürecinden geçmek ve gereksiz ve gayrimeşru ödemeler yapmak gerektiğinden bahseden yazıları bulunmaktadır. Haydar Kazgan, Osmanlı'dan Cumhuriyet'e Şirketleşme, Töbank, İstanbul 1991, s. 20.
} 
işleyişinde "şikayet mekanizması" önemli bir yer tutmaktadır. Osmanlı yönetiminin fabrikaların inşasına dair aldığı kentsel ve mimari kararlarda da büyük oranda "şikayet mekanizması"nın etkili olduğu anlaşılmaktadır. Şikayet mekanizmasıyla yerel yönetimler bazında sonuç alınan örnekler mevcuttur. Bununla birlikte artan şikayetler nedeniyle Bab-1 Ali yönetimi daha kapsayıcı önlemler almaya karar vermiştir. Osmanlı yöneticilerinin bu konudaki çözüm arayışları fabrikaların inşasına dair nizamnameler hazırlamak, yer seçimi ile ilgili kısıtlamalar getirmek ve ruhsat alımını merkezileştirerek denetimi artırmaya çalışmak şeklinde ortaya çıkmıştır. Türkiye'de sanayinin yer seçiminde çevresel etkileri göz önünde bulunduran yürürlükteki yasa Hıfzısıhha Kanunu'dur. Sanayileri gruplayarak yerleşim yerlerine mesafesini belirleyen bu yasa 1930'larda yürürlüğe girmiş olup, kökeni 19. yüzyılda Osmanlı yönetiminin hazırladığı nizamnamelere ve kurallara dayanmaktadır.

Osmanlı yönetimi "sanayi bölgeleri” planlamamış, 19. yüzyılın ikinci yarısından itibaren hazırladığı nizamnamelerle "sanayinin yasak olduğu bölgeleri" tanımlamıştır. İstanbul için Boğaz'ın her iki yakası ile Marmara sahillerini içine alan bir "hudud-ı memnu" tanımlanmış, sağlı̆̆ i ihlal eden sanayi dalları sınıflandırılmış, imalat yapılan yerlerin yerleşim yerlerine olması gereken mesafeleri belirlenmiştir. Ancak tarif olunan hudut dahilindeki mahaller aynı zamanda su kenarı olmaları nedeniyle sanayi tesisleri için en çok tercih edilen bölgelerdir. Dolayısıyla yasağın uygulanmasında zorlanılmış, gerek Boğaz'da ve gerekse Haliç’te sanayileşmenin olumsuz etkilerine karşı önlemler alınmaya çalışılsa da kent açısından 20. yüzyılın ikinci yarısına kadar devam edecek sorunların başlangıcı olmuştur.

\section{Kaynakça}

\section{Arșiv Kaynakları}

Başbakanlık Osmanlı Arşivi (BOA)

Bab-1 Ali Evrak Odası (BEO.)

Cevdet/ Askeriye (C.AS.)

Cevdet/ İktisat (C.İKTS.)

Cevdet/ Sihhiye (C.SH.)

Dahiliye/ İdare (DH.ID.)

Dahiliye/ Mektubi Kalemi (DH.MKT)

Dahiliye/ Umur-1 Mahalliye-i Vilayat Müdüriyeti Belgeleri (DH.UMVM.)

Hariciye Nezareti/ Mektubi Kalemi (HR.MKT.)

Hariciye Nezareti/ Tercüme Odası (HR.TO.)

Hatt-1 Hümayun (HAT.)

İradeler/ Dahiliye (I.DH.)

İradeler/ Dosya Usulü (İ.DUIT.)

İrade/ Meclis-i Vala (İ.MVL.)

Meclis-i Vükela Mazbataları (MV.)

Sadaret/ Mühimme Kalemi Evrakı (A.MKT.MHM.) 
19. Yüzyılda Inşa Edilen Fabrika Yapılarının Kent Üzerindeki Olumsuz Etkileri ve Osmanlı Yönetiminin...

Sadaret/ Nezaret ve Devair Evrakı (A.MKT.NZD.)

Şuray-1 Devlet (Ş.D.)

Ticaret, Nafia, Ziraat, Orman, Meadin Nezaretleri Defterleri (T.d.)

Ticaret, Nafia, Ziraat, Orman, Meadin Nezaretleri/ Heyet-i Fenniye (T.HFN.)

Yıldız/ Askeri Maruzat (Y.PRK.ASK.)

Yildı/ Hususi Maruzat (Y.A.HUS)

Yıldız/ Mütenevvi Maruzat (Y.MTV.)

Yıldız/Tahrirat-1 Ecnebiyye ve Mabeyn Mütercimliği (Y.PRK.TKM.)

\section{Kitap, Makale ve Tezler}

ACAR, Gevher, Tanzimat Dönemi Fikir ve Düşünce Hayatının Mimari Alana Yansıması, (Mimar Sinan Üniversitesi Sosyal Bilimler Enstitüsü Yayınlanmamış Doktora Tezi), İstanbul 2000, s. 65-69.

AKKURT, Hümeyra Birol, 19. Yüzyll Batılılaşma Kesitinde Bornova, Buca Levanten Köşkleri Mekansal Kimliğinin Irdelenmesi, (Dokuz Eylül Üniversitesi Fen Bilimleri Enstitüsü Yayınlanmamış Doktora Tezi), İzmir 2004.

BAYRAKTAROĞLU, Sena, Developments of Railways in the Ottoman Empire and Turkey, (Boğaziçi Üniversitesi Sosyal Bilimler Enstitüsü Yayınlanmamış Yüksek Lisans Tezi), İstanbul 1995.

BENEVOLO, Leonardo, Avrupa Tarihinde Kentler, Literatür Yayınlar1, İstanbul 2006.

BİLİK, Erol, "İngiltere'de Sağlı Hizmetleri”, Ankara Üniversitesi Hukuk Fakültesi Dergisi, C.7, S. 1-4, 1950, s. 192-213.

BİROL, Gaye, "Modern Mimarlığın Ortaya Çıkışı ve Gelişimi”, Megaron Mimarlar Odası Balıkesir Şubesi Dergisi, S.1, 2006, s. 3-16.

BOYACIOĞLU, Didem, "Tanzimat'tan Cumhuriyet'e Osmanlı Fabrika Yapılarının İnşasına Dair Yapılan Düzenlemeler”, Uluslararası Sosyal Araştırmalar Dergisi, C.8, S. 38, 2015, s. 471-486.

CLARK, Edward C., "Osmanlı Sanayi Devrimi”, Ed. Ekmeleddin İhsanoğlu, Osmanlılar ve Batı Teknolojisi Yeni Araştırmalar, Yeni Görüşler, İstanbul Üniversitesi Edebiyat Fakültesi Yayınları, İstanbul 1992, s. 37-52.

ÇELIK, Zeynep, 19. Yüzyılda Osmanlı Başkenti, Değişen İstanbul, Tarih Vakfı Yurt Yayınları, İstanbul 1998.

DICKENS, Charles, Zor Zamanlar, çev. Füsun Elioğlu, Oda Yayınları, İstanbul 2017.

DÜNDAR, Abdülkadir, Arşivlerdeki Plan ve Çizimler Işı̆̆ Altında Osmanlı İmar Sistemi, XVIII. Ve XIX. Yüzyıl, T.C. Kültür Bakanlığı Yayınları, Ankara 2000.

ENGIN, Vahdettin, “Osmanlı' da Çevre Şuuru”, Tarih ve Medeniyet, S.7, 1994, s.35-38.

GOODMAN, David C.- Colin Chant, The European Cities and Technology. Routledge, London 1999.

GÖLEN, Zafer, Osmanlı Devleti'nde Baruthane-i Amire, Türk Tarih Kurumu Yayınları, Ankara 2006. 
GÜL, Murat- Richard Lamb, "Mapping, Regularizing and Modernizing Ottoman İstanbul: Aspects of the Genesis of the 1839 Development Policy", Urban History, C.31, S.3, Cambridge 2004, s.420-436.

İHSANOĞLU, Ekmeleddin, “Osmanlı İmparatorluğu'nda Bilim, Teknoloji ve Sanayide Modernleşme Gayretleri” Haz. Feza Günergun, Osmanlı Bilimi Araştırmaları II, İstanbul Üniversitesi Edebiyat Fakültesi Yayınları, İstanbul 1998, s. 1-22.

KAÇAR, Mustafa- Tuncay Zorlu- Burak Barutçu- Atilla Bir- C.Ozan Ceyhan- Aras Neftçi, İstanbul Teknik Üniversitesi ve Mühendislik Tarihimiz, Ed. Mehmet Karaca, İTÜ Vakfı Yayınları, İstanbul 2012.

KARAVAR, Hilal, Osmanlı'dan Cumhuriyet'e İzmit Çuha Fabrikası 1844-1920, Kocaeli Büyükşehir Belediyesi Kültür Yayınları, Kocaeli 2007.

KARAYAMAN, Mehmet, “Osmanlı Devleti'nde Şeker Fabrikası Kurma Teşebbüsleri”, Tarih Incelemeleri Dergisi, C. XXV, S.1, 2010, s. 297-318.

KAYGALAK, Sevilay, “Osmanlı'da Kentsellik ve Kentler: Kent Tarihi Yazımında Kültürelciliklerin Ötesine Geçebilmek”, Mülkiye Dergisi, C. XXIX, S. 246, 2005, s.19-36.

KAZGAN, Haydar, Osmanlı'dan Cumhuriyet'e Şirketleşme, Töbank, İstanbul 1991.

KÖKSAL, Tayyibe Gül, Haliç Tersanelerinin Tarihsel-Teknolojik Gelişim Süreci ve Koruma Önerileri, (İstanbul Teknik Üniversitesi Fen Bilimleri Enstitüsü Yayınlanmamış Yüksek Lisans Tezi), İstanbul 1996.

KÜÇÜKERMAN, Önder, Geleneksel Türk Dericilik Sanayii ve Beykoz Fabrikası, Sümerbank, İstanbul 1988.

MARTAL, Abdullah, "16. Yüzyıldan 20. Yüzyıla Ticaret ve Sanayinin Gelişimi”, Ed. Enis Batur, Üç İzmir, Yapı Kredi Yayınları, İstanbul 1992, s. 265-271.

MUNCE, James F., Industrial Architecture, An Analysis of International Building Practice, F.W. Dodge Corporation, New York 1960.

MULLER-WIENER, Wolfgang., "15-19. Yüzyıllar Arasında İstanbul'da İmalathane ve Fabrikalar", Ed. Ekmeleddin İhsanoğlu, Osmanlılar ve Batı Teknolojisi Yeni Araştırmalar, Yeni Görüşler, İstanbul Üniversitesi Edebiyat Fakültesi Yayınları, İstanbul 1992, s. 52-118.

OKTAR, Tiğinçe- Hamdi Genç, “Osmanlı İstanbulu'nda Haliç ve Çevresinde Kirlilik Sorunu”, Haz. Süleyman Faruk Göncüoğlu, Dünü ve Bugünü ile Haliç Sетроzуити 22-23 Mayıs 2003, Kadir Has Üniversitesi Yayınları, İstanbul 2004, s. 583-590.

ÖZTÜRE, Öztüre, Nicomedia İzmit Tarihi, Çeltüt Matbaac1lık, İstanbul 1969.

"Sabit Buhar Makinelerine Dair Nizamname", Düstur, Birinci Tertip, C. 2, Matbaa-y1 Amire, Dersaadet 1872, s. 441-445.

QUATAERT, Donald, "Fabrika Bacalarından Tüten İlk Dumanlar", Haz. Gilles Veinstein, Selanik 1850-1918: Yahudilerin Kenti ve Balkanlar'in Uyanışl, İletişim Yayınları, İstanbul 2001, s. 186-204. 
19. Yüzyılda Inşa Edilen Fabrika Yapılarının Kent Üzerindeki Olumsuz Etkileri ve Osmanlı Yönetiminin...

SARI, Tanju, Osmanlı Imparatorluğu'nda Sanayileşme Çerçevesinde İstanbul'daki Fabrikaların Oluşum ve Gelişimi, (Marmara Üniversitesi Sosyal Bilimler Enstitüsü Yayınlanmamış Doktora Tezi), İstanbul 2006.

SERIN, Sinem, Yıldız Çini/Porselen Fabrikası, (İstanbul Üniversitesi Sosyal Bilimler Enstitüsü Yayınlanmamış Yüksek Lisans Tezi), İstanbul 2009.

SYMONDS, J., "Dirty Old Town? Industrial Archaeology and the Urban Historic Environment", Industrial Archaeology Review, C. XXVII, S.1, 2005, s.57-65.

ŞENER, Sefer, “Osmanlı Sanayileşme Süreci ve bu Süreçte Özel Girişimin Rolü”, Dokuz Eylül Üniversitesi Sosyal Bilimler Enstitüsü Dergisi, C. 9, S.3, 2007, s. 56-90.

ŞIMŞEK, Eylem, Endüstri Yapılarının Kültürel Miras Olarak Irdelenmesi ve Değerlendirilmesi: İzmir Liman Arkası Bölgesi Örneği, (Dokuz Eylül Üniversitesi Fen Bilimleri Enstitüsü Yayınlanmamış Yüksek Lisans Tezi), İzmir 2006.

TANYELİ, Uğur, "Transfer of Western Urban Planning Concepts and the Techniques to Turkey (1718-1840)", Ed. Ekmeleddin İhsanoğlu, Transfer of Modern Science and Technology to the Muslim World, IRCICA Yayınları, İstanbul 1992, s. 345363.

TEKELİ, Tekeli, "19. Yüzyılda İstanbul Metropol Alanının Dönüşümü”, Ed. Paul Dumont, François Georgeon, Modernleşme Sürecinde Osmanlı Kentleri, Tarih Vakfi Yurt Yayınları, İstanbul 1992, s. 19-30.

TEKELI, İlhan- Selim İlkin, Cumhuriyet'in Harcı: Modernitenin Altyapısı Oluşurken, İstanbul Bilgi Üniversitesi Yayınları, İstanbul 2004.

TEKELI, İlhan, Sanayi Toplumu İçin Sanayi Yazıları, Tarih Vakfı Yurt Yayınları, İstanbul 2010

TEKIN, Zeki, Tanzimat Dönemine Kadar Osmanlı İstanbul'unda Dericilik, (Marmara Üniversitesi Türkiyat Araştırmaları Enstitüsü Yayınlanmamış Doktora Tezi), İstanbul 1992.

TÜRKHAN, Mehmet Sait, “19 ve 20. yy'da Haliç’te Çevre Sorunları ve Deniz Kirliliği”, Toplumsal Tarih, S.169, İstanbul 2008, s. 60-66. 


\section{Ekler}

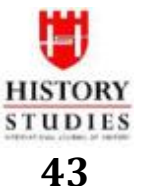

Volume 10

Issue 9

December 2018

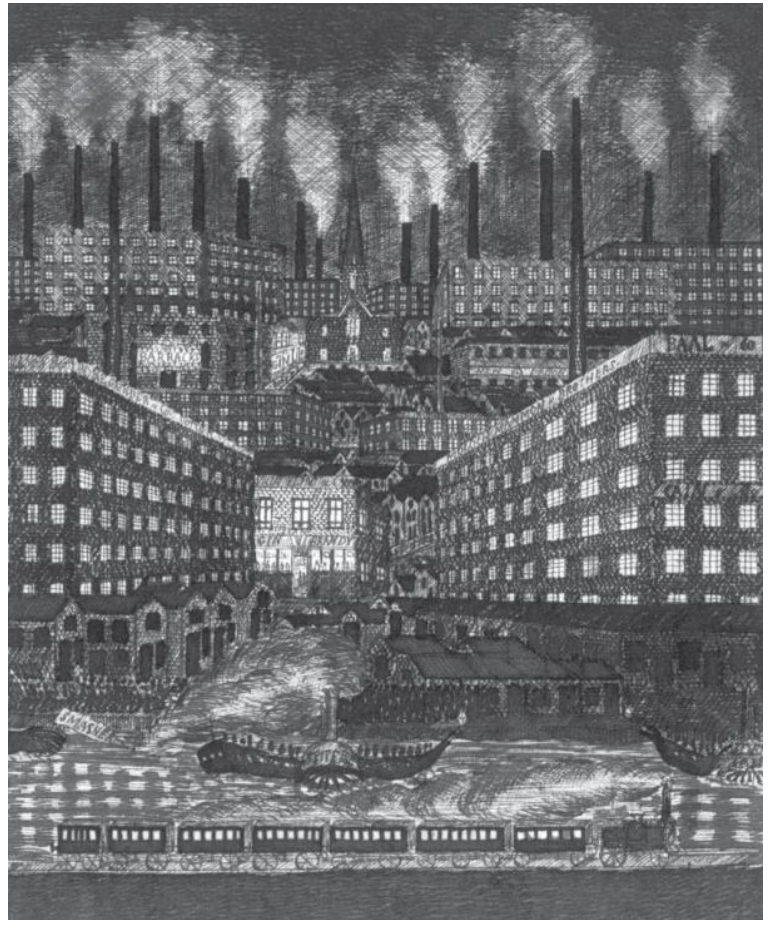

Ek 1. Ernest Jones'un $1848-1850$ yılları arasındaki mahkumiyeti sırasında resmettiği endüstriyel kent (Kaynak: Symonds, 2005, s. 58).

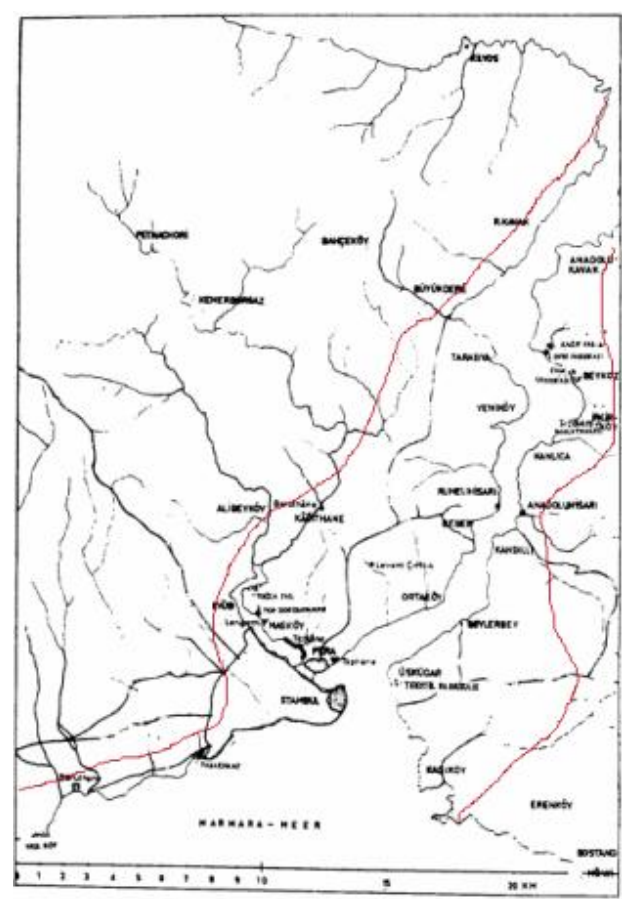

Ek 2. Nizamnameler ile tanımlanan fabrikaların inşasının yasak olduğu tahmini sınırlar, (Harita Müller- Wiener'den uyarlanmıştır.)(Kaynak: Müller- Wiener, 1992, s. 72)

\section{Journal of History Studies}

